NUREG/CR-6563

\title{
Lg Excitation, Attenuation, and Source Spectral Scaling in Central and Eastern North America
}

Manuscript Completed: September 1997

Date Published: October 1997

Prepared by

B. J. Mitchell, J. Xie, S. Baqer

Department of Earth and Atmospheric Sciences

Saint Louis University

3507 Laclede Avenue

St. Louis, MO 63103

E. Zurflueh, NRC Project Manager

Prepared for

Division of Engineering Technology

Office of Nuclear Regulatory Research

U.S. Nuclear Regulatory Commission

Washington, DC 20555-0001

NRC Job Code W6376
DSTRRIMUTON OF THIS DOCUMENT IS UNLLAIFED

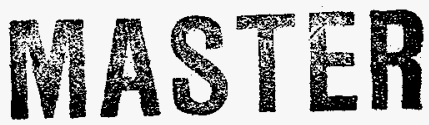

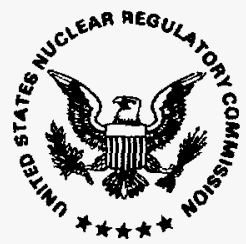




\section{DISCLAIMER}

This report was prepared as an account of work sponsored by an agency of the United States Government. Neither the United States Government nor any agency thereof, nor any of their employees, make any warranty, express or implied, or assumes any legal liability or responsibility for the accuracy, completeness, or usefulness of any information, apparatus, product, or process disclosed, or represents that its use would not infringe privately owned rights. Reference herein to any specilic commercial product, process, or service by trade name, trademark, manufacturer, or otherwise does not necessarily constitute or imply its endorsement, recommendation, or favoring by the United States Government or any agency thereof. The views and opinions of authors expressed herein do not necessarily state or reflect those of the United States Government or any agency thereof. 


\section{DISCLAMIER}

Portions of this doccoment moy be illegible in electronic image products. Images are produced from the best apailable original doecoment. 


\begin{abstract}
Seismic moments and corner frequencies were obtained for many earthquakes in the central and eastern United States, and for a few events in the western United States, using the Lg phase and a recently developed inversion algorithm. Additionally, Q values for the Lg phase along paths to individual stations were obtained simultaneously with the source parameters. Both corner frequencies and magnitudes were found to vary systematically with moment. For moments between 0.15 and $400 \times 10^{15} \mathrm{~N}-\mathrm{m}$ corner frequencies vary between about 4 and $0.2 \mathrm{~Hz}$ while body-wave magnitude varies between about 3.5 and 5.8. A map of $\mathrm{Lg} \mathrm{Q}$ values displays a systematic decrease from east to west. Maximum and minimum values are 989 and 160 , respectively.

Lg coda $Q$ values were obtained for the entire United States with excellent coverage in the eastern and western portions of the country and somewhat poorer coverage in the central portion. Lg coda Q is highest (700-750) in a region of the northeastern United States that includes portions of New York and Pennsylvania and lowest $(>200)$ in California. Lg coda Q is lower (250-450) everywhere west of the Rocky Mountains than in the rest of the country (450-750). Q determinations for both the direct $\mathrm{Lg}$ phase and $\mathrm{Lg}$ coda indicate that, for an earthquake of a given magnitude, $\mathrm{Lg}$ and its coda will propagate much more efficiently, and cause damage over a wider area, in the eastern and central United States than it will in the western United States.
\end{abstract}



Table of Contents

1. Introduction

2. Lg and Lg Coda

1

3. The Direct Lg Phase

2

4. Lg Coda $Q$ 7

5. Conclusions 41

6. References 41 


\section{List of Figures}

1. Example showing the $\mathrm{Lg}$ phase recorded at four stations in the United States

2. Earthquakes and great-circle paths used for the determination of source parameters and $\mathrm{Lg} \mathrm{Q}$ in the United States

3. Corner frequency versus seismic moment for events studied. The solid circles are for events recorded at more than two stations.

4. Magnitude versus seismic moment for events studied. The solid circles are for events recorded at more than two stations.

5. Lg Q values for paths between events studied and selected stations

6a. Comparison of observed and predicted source spectra for the earthquake of January 29,1990

6b. Comparison of observed and predicted source spectra for the earthquake of April 18, 1990

6c. Comparison of observed and predicted source spectra for the earthquake of September 9, 1990

$6 \mathrm{~d}$. Comparison of observed and predicted source spectra for the earthquake of October 19, 1990

6e. Comparison of observed and predicted source spectra for the earthquake of October 24, 1990

6f. Comparison of observed and predicted source spectra for the earthquake of December 31, 1990

6g. Comparison of observed and predicted source spectra for the earthquake of January 2, 1992

6h. Comparison of observed and predicted source spectra for the earthquake of January 7,1996

6i. Comparison of observed and predicted source spectra for the earthquake of February 6, 1996

6j. Comparison of observed and predicted source spectra for the earthquake of February 20, 1996

6k. Comparison of observed and predicted source spectra for the earthquake of March 1, 1996

61. Comparison of observed and predicted source spectra for the earthquake of March 19, 1996

$6 \mathrm{~m}$. Comparison of observed and predicted source spectra for the earthquake of March 25, 1996 
6n. Comparison of observed and predicted source spectra for the earthquake of May 16, 1996

6o. Comparison of observed and predicted source spectra for the earthquake of August 16, 1996

7. The linear regression determination of $\mathrm{Lg}$ coda $\mathrm{Q}$ at $1 \mathrm{~Hz}$ and it frequency dependence

8. The theoretical elliptical pattern sampled by Lg coda. The size of the area depends on the maximum lapse time and the location of both the seismic source and the recording site.

9. Distribution of $\mathrm{Lg}$ coda $\mathrm{Q}$ at $1 \mathrm{~Hz}$ for the United States

10. $\mathrm{Lg}$ coda $\mathrm{Q}$ at $1 \mathrm{~Hz}$

11. Frequency dependence of $\mathrm{Lg}$ coda $\mathrm{Q}$

12. Relative value of $\mathrm{psf}$

13. Standard error for $Q_{o}$

14. Standard error for frequency dependence 


\section{Introduction}

Over the period of this contract we have conducted research along three major lines. First, we have determined source properties of earthquakes (moment and corner frequency), primarily in the central and eastern United States. Second, we have determined Lg Q along paths from events, for which we have determined source properties, to numerous stations in North America. Most of these stations are in the central and eastern United States, but a few of them are in the western United States. The determinations of source properties and path-dependent $\mathrm{Lg} \mathrm{Q}$ were performed simultaneously using a method developed for studies in Eurasia (Xie et al., 1996; Cong et al., 1996). Third, we developed a map of $\mathrm{Lg}$ coda $\mathrm{Q}$ variation for the entire United States. For the development of that map we measured Lg coda $Q$ for numerous paths across the entire United States using a modern stacking technique (Xie and Nuttli, 1988) and inverted those values to obtain a tomographic image of the variations using a method developed by Xie and Mitchell (1990a).

The moment and corner frequency values that we have obtained enable us to infer how moment relates to corner frequency and to reported magnitudes of selected events. Our results show that regional variations of $\mathrm{Lg} Q$ and $\mathrm{Lg}$ coda $\mathrm{Q}$ can be related to past tectonics, with the lowest values occurring in regions that have undergone the most recent tectonic activity (Mitchell, 1995).

\section{Lg and Lg Coda}

$\mathrm{Lg}$ is often the most prominent and robust phase on short-period and broad-band seismograms recorded in continental regions. For that reason it has been used to determine magnitudes of small events at regional distances (Baker, 1970; Nuttli, 1973), yields of nuclear explosions (Nuttli, 1986), and regional variations of crustal attenuative properties (e.g. Mitchell, 1981; Campillo and Plantee, 1991). It can be treated as a superposition of higher-mode surface waves that propagate in the continental crust (Knopoff et al., 1973; Panza and Calcagnile, 1975; Kennett, 1984). The onset of Lg arrives with a group velocity of $3.3-3.6 \mathrm{~km} / \mathrm{s}$, with young active regions being slower than stable shields.

A coda of up to several minutes duration follows Lg, the predominant frequency of which is lower than the direct phase, and decreases with time. The arrival of $\mathrm{Lg}$ coda energy is omnidirectional, indicating that is scattered from heterogeneities in the crust (Der et al., 1984). Being a scattered wave, it is sensitive to properties in a volume of the crust that surrounds the great circle path, including both the seismic source and the receiver, rather than to properties along a single ray path between them. Scattering had earlier been inferred as the cause for coda following body waves at short distances (Aki, 1969; Aki and Chouet, 1975).

The attenuation of both $\mathrm{Lg}$ and $\mathrm{Lg}$ coda is often expressed as the inverse of a quality factor, $\mathrm{Q}$. In the present report, we use $\mathrm{Q}_{\mathrm{Lg}}$ and $\mathrm{Q}_{\mathrm{Lg}}^{\mathrm{c}}$ to denote, respectively, the quality factors of the direct $\mathrm{Lg}$ phase and $\mathrm{Lg}$ coda. $\mathrm{Q}_{\mathrm{Lg}}$ can be described by the equation

$$
\mathrm{Q}_{\mathrm{Lg}}=\mathrm{Q}_{\mathrm{o}} f^{\eta}
$$

where $Q_{0}$ is $\operatorname{Lg} Q$ at a frequency $(f)$ of $1 \mathrm{~Hz}$ and $\eta$ is the frequency dependence of $\mathrm{Lg}$ coda $Q$ in the frequency range near $1 \mathrm{~Hz}$. The same form of equation can be used to describe $Q_{L g}^{c}$ but, of course, $Q_{0}$ and $\eta$ may take on different values than those for $Q_{L g}$ in any region. 
Figure 1 shows examples of $\mathrm{Lg}$ and its coda for four paths in the United States. The uppermost trace is for a path in the eastern United States, the middle two traces are for paths in the central United States, and the lowest trace is for a path in the western United States. Note that the frequency content of the trace for the western United States covers a lower range of frequencies than that covered for the other traces. The high-frequency energy has been damped much more rapidly in the western portion of the United States than in the eastern portion.

\section{The Direct $\mathrm{Lg}$ Phase}

Method for obtaining Earthquake Source Parameters and Lg $Q$

Xie (1993) developed a method for simultaneous inversion of $\mathrm{Lg}$ spectral parameters $\left(M_{o}\right.$ and $\left.f_{c}\right)$ and path-variable $Q_{o}$ and $\eta(L g Q$ and its frequency dependence) using $\mathrm{Lg}$ spectra from a single event. It was recently applied to nuclear explosions (Xie et al., 1996) and earthquakes (Cong et al., 1996) in Eurasia. The method is described in detail in Xie (1993), so will only be briefly summarized here.

The $\mathrm{Lg}$ spectrum is expressed as a product of (1) the $\mathrm{Lg}$ source spectrum (assumed to be a simple Brune source), (2) the source radiation spectrum for the higher-mode surface waves that comprise $\mathrm{Lg}$, (3) an exponential factor that includes frequency raised to the (1$\eta$ ) power, (4) the mean $\mathrm{Lg}$ travel time, (5) $Q_{0}$, and (6) a randomness factor. For each event studied, that expression can be solved by non-linear least-squares to obtain $M_{\circ}$ and $\eta$ for the event as well as $Q_{0}$ and $\eta$ for all paths between the event and the stations that recorded it.

\section{Earthquake Source Parameters}

The earthquakes for which moment $\left(M_{o}\right)$ and corner frequency $\left(f_{c}\right)$ were determined are listed in Table 1. Twenty-eight of these events were situated such that paths to recording stations lie entirely or predominantly in either the central or eastern United States. The other three earthquakes occurred in California and paths to recording stations lie in the western United States. Events, stations, and paths appear on the map in Figure 2. In addition to hypocentral information, Table 1 presents body-wave magnitudes $\left(m_{b}\right)$ reported by the NEIC, $M_{o}$ and $f_{c}$ values obtained in our research and the number of stations used for the analysis of each event.

Figure 3 plots corner frequency $\left(f_{c}\right)$ versus seismic moment $\left(M_{o}\right)$ for the events used in our work. The solid symbols dencte results for which three or more stations were used in the analysis and the open symbols denote results for events in which one or two stations were used. A least-squares fit to the solid symbols (solid line) yields the $M_{o}-f_{c}$ relation

$$
\log \left(M_{0}\right)=15.36( \pm 0.48)-2.32( \pm 0.36) \log \left(f_{c}\right)
$$

while all symbols yield the relation

$$
\log \left(M_{o}\right)=15.29( \pm 0.50)-1.97( \pm 0.25) \log \left(f_{c}\right) .
$$

The equations are the same, within calculated uncertainties. Taking into consideration the large uncertainties in these determinations, they are roughly consistent with values plotted in a compilation by Haar et al. (1986). 




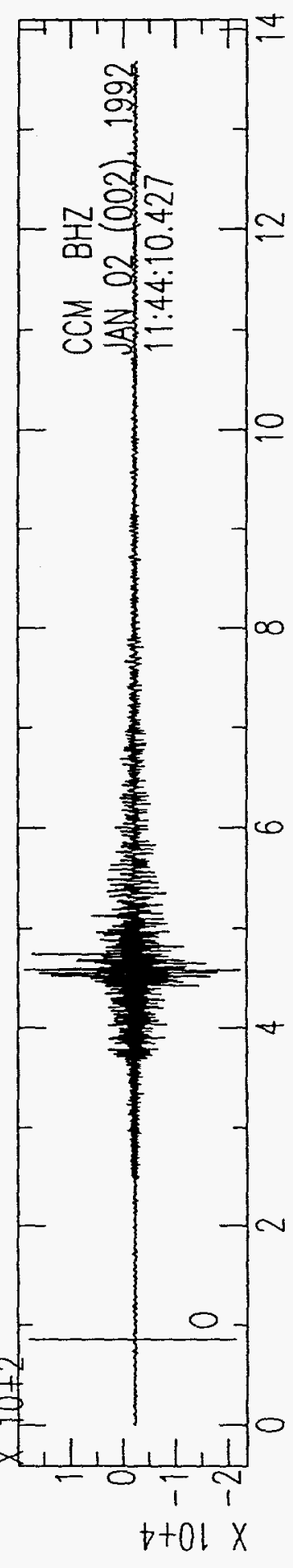

NUREG/CR-6563 
Table 1. Earthquakes used for determination of source parameters for the United States

\begin{tabular}{|c|c|c|c|c|c|c|c|c|c|}
\hline $\begin{array}{c}\text { Event } \\
\text { No }\end{array}$ & $\begin{array}{c}\text { Date } \\
(\mathrm{m} \mathrm{d} \mathrm{y})\end{array}$ & $\begin{array}{c}\text { Origin time } \\
(\mathrm{h}: \mathrm{m}: \mathrm{s})\end{array}$ & Latitude & Logitude & $\begin{array}{c}\text { Depth } \\
(\mathrm{km})\end{array}$ & $\begin{array}{c}\mathrm{m}_{\mathrm{b}} \\
(\mathrm{mb})\end{array}$ & $\begin{array}{c}\mathrm{M}_{0} \\
\left(\times 10^{15} \mathrm{~N}-\mathrm{m}\right) \\
\end{array}$ & $\begin{array}{c}f_{c} \\
(\mathrm{~Hz})\end{array}$ & $\begin{array}{c}\text { No. of } \\
\text { stations }\end{array}$ \\
\hline 1 & 012990 & $13: 16: 10.60$ & 34.463 & -106.879 & 12.0 & 4.5 & 0.9 & 1.12 & 1 \\
\hline 2 & 041890 & $13: 53: 51.40$ & 36.910 & -121.652 & 05.0 & 5.4 & 11.0 & 0.30 & 2 \\
\hline 3 & 092690 & $13: 18: 51.30$ & 37.165 & -089.577 & 12.0 & 4.7 & 2.2 & 1.36 & 2 \\
\hline 4 & 101990 & $07: 01: 57.40$ & 46.470 & -075.590 & 13.0 & 4.6 & 5.8 & 1.40 & 2 \\
\hline 5 & 102490 & $06: 15: 20.70$ & 38.047 & -119.157 & 12.0 & 5.4 & 15.0 & 0.30 & 4 \\
\hline 6 & 123190 & 03:53:58.30 & 47.579 & -072.556 & 18.0 & 4.2 & 0.9 & 1.18 & 1 \\
\hline 7 & 010292 & $11: 45: 35.60$ & 32.336 & -103.101 & 05.0 & 4.6 & 1.5 & 1.30 & 2 \\
\hline 8 & 082192 & $16: 31: 55.10$ & 33.050 & -080.116 & 10.0 & 4.1 & 5.0 & 0.25 & 1 \\
\hline 9 & 082292 & $12: 20: 32.60$ & 39.106 & -070.319 & 10.0 & 4.8 & 53.5 & 0.20 & 3 \\
\hline 10 & 111792 & $03: 58: 00.90$ & 45.764 & -074.862 & 18.0 & 4.0 & 1.5 & 0.50 & 1 \\
\hline 11 & 040993 & $12: 29: 19.10$ & 28.811 & -098.124 & 05.0 & 4.1 & 7.0 & 0.45 & 4 \\
\hline 12 & 060293 & 02:08:32.70 & 25.946 & -109.989 & 10.0 & 4.7 & 16.5 & 0.70 & 3 \\
\hline 13 & 120593 & $00: 58: 20.20$ & 27.831 & -102.737 & 05.0 & 4.7 & 15.0 & 0.60 & 4 \\
\hline 14 & 011694 & $00: 42: 43.24$ & 40.327 & -076.007 & 05.0 & 4.2 & 0.25 & 3.60 & 2 \\
\hline 15 & 011694 & $01: 49: 16.20$ & 40.330 & -076.037 & 05.0 & 4.6 & 3.2 & 1.30 & 4 \\
\hline 16 & 051294 & $00: 22: 21.80$ & 24.953 & -109.284 & 10.0 & 4.7 & 88.0 & 0.40 & 1 \\
\hline 17 & 051294 & $01: 14: 02.20$ & 24.678 & -109.188 & 10.0 & 4.2 & 14.0 & 0.20 & 1 \\
\hline 18 & 091394 & $06: 01: 23.00$ & 38.156 & -107.982 & 10.0 & 4.4 & 5.0 & 0.40 & 3 \\
\hline 19 & 092594 & $00: 53: 28.00$ & 47.770 & -069.950 & 18.0 & 4.1 & 0.3 & 2.20 & 3 \\
\hline 20 & 020395 & $15: 26: 10.07$ & 41.527 & -109.639 & 01.0 & 5.2 & 10.0 & 0.80 & 4 \\
\hline 21 & 031195 & $08: 15: 52.00$ & 36.983 & -083.150 & 01.0 & 3.8 & 1.5 & 0.90 & 4. \\
\hline 22 & 041495 & $00: 32: 54.20$ & 30.244 & -103.325 & 05.0 & 5.7 & 280 & 0.30 & 5 \\
\hline 23 & 052795 & $19: 51: 10.40$ & 36.170 & -089.430 & 06.0 & 3.8 & 0.6 & 1.80 & 5 \\
\hline 24 & 010796 & $14: 32: 53.10$ & 35.766 & -117.649 & 06.0 & 4.6 & 26.0 & 0.33 & 3 \\
\hline 25 & 020696 & $15: 10: 27.60$ & 42.500 & -097.500 & shallow & 3.6 & 0.19 & 1.97 & 2 \\
\hline 26 & 022096 & $14: 40: 41.90$ & 27.552 & -111.678 & 10.0 & 4.3 & 9.10 & 0.39 & 2 \\
\hline 27 & 030196 & $11: 49: 14.70$ & 29.499 & -113.627 & 10.0 & 4.1 & 12.4 & 0.31 & 1 \\
\hline 28 & 031996 & $15: 31: 36.40$ & 25.006 & -109.320 & 10.0 & 5.0 & 53.0 & 0.24 & 3 \\
\hline 29 & 032596 & $14: 15: 50.40$ & 32.100 & -088.700 & shallow & 3.5 & 0.15 & 2.20 & 2 \\
\hline 30 & 051696 & $15: 14: 01.90$ & 42.587 & -111.202 & 05.0 & 3.9 & 0.80 & 0.80 & 2 \\
\hline 31 & 081696 & $04: 56: 46.00$ & 49.210 & -082.920 & 18.0 & 3.5 & 0.16 & 1.80 & 3 \\
\hline
\end{tabular}

The origin times and locations are from the U.S. Geological Survey's Preliminary Determination of Epicenters. 
3. The Direct Lg Phase

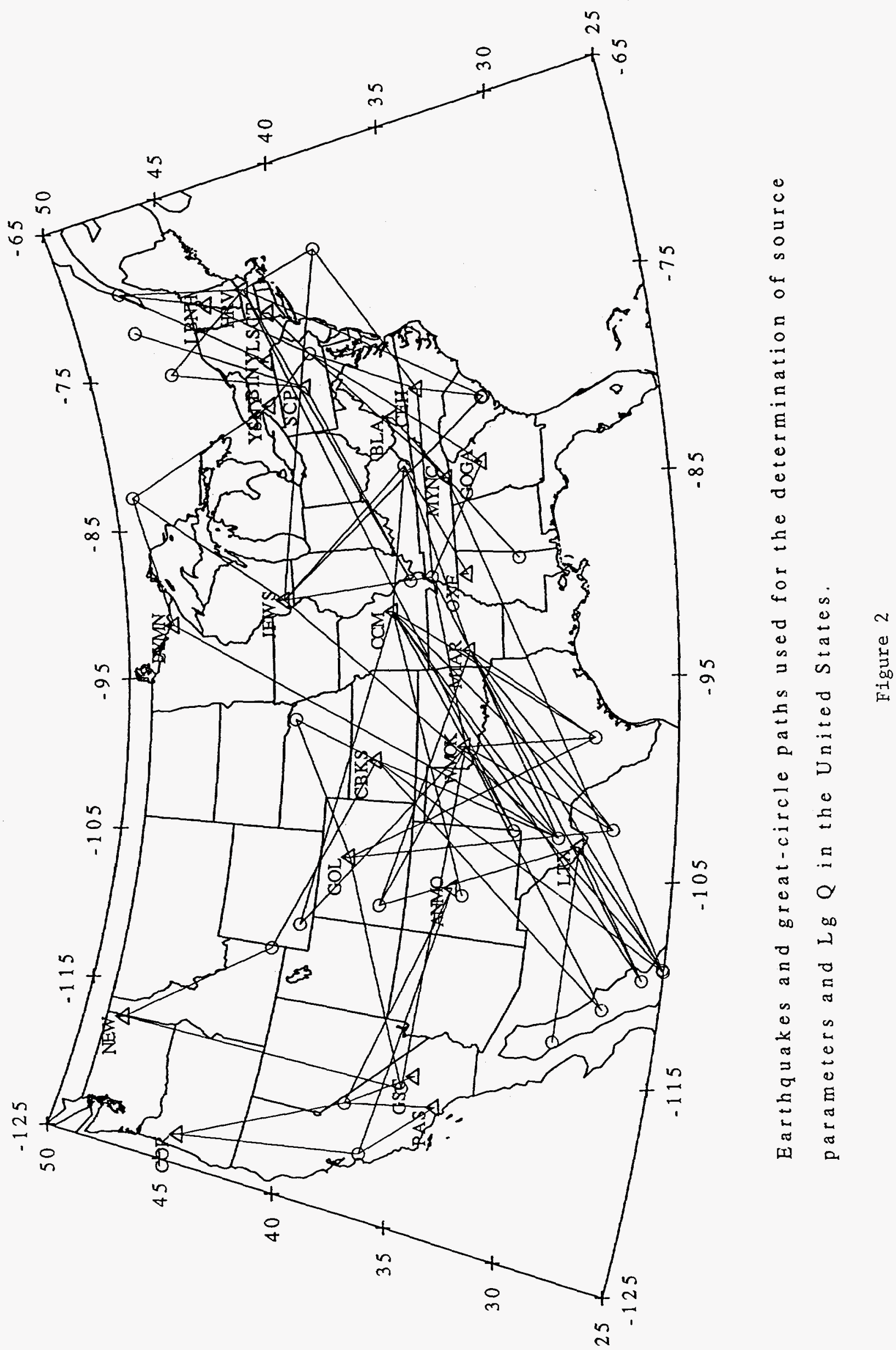


3. The Direct Lg Phase




Using reported $\mathrm{m}_{b}$ values, we can also determine moment-magnitude relations for events in the United States (Figure 4). As with Figure 3, solid symbols denote events for which three or more stations were used in the analysis and open symbols denote events for which one or two stations were used. A linear least-squares fit to the solid symbols (solid line) yields the $M_{o}-m_{b}$ relation

$$
\log \left(\mathrm{M}_{\mathrm{o}}\right)=10.20( \pm 1.08)+1.24( \pm 0.21) \mathrm{m}_{\mathrm{b}}
$$

while all symbols yield the relation

$$
\log \left(\mathrm{M}_{\mathrm{o}}\right)=10.41( \pm 1.00)+1.18( \pm 0.19) \mathrm{m}_{\mathrm{b}}
$$

As with the moment - corner frequency relation, these equations are the same, within the calculated uncertainties.

\section{Lg $Q$ Values}

During the inversion for source parameters for each event, we simultaneously determined $Q_{0}$ and $\eta$ along all individual paths to stations. The $Q_{0}$ values appear in the map in Figure 5 and are listed in Table 2. The highest values occur in regions of the northeastern and the central United States while the lowest values are in the westernmost United States. Our pattern of $\mathrm{Lg} \mathrm{Q}$ in the northeastern region is roughly consistent with the values of Shi et al. (1996) there. Their values, at $1 \mathrm{~Hz}$, vary between about 550 and 850 , while for paths for that region, in our study, Lg Q varies between 600 and 720 . Most of our paths crossing that region, however, are much longer that those of Shi et al. (1996) and are likely to traverse crust with laterally varying attenuative properties. Some values in Figure 5 seem unrealistic and are not consistent with other values in the region. For instance, values of 222 and 252 along paths from an earthquake in southern Texas to stations in Missouri and Arkansas seem unrealistically low. Such values may occur because the $\mathrm{Lg}$ radiation is not really radially symmetric as assumed in the inversion process. For that reason, we think that $\mathrm{Lg}$ coda will provide more reliable values of $Q$. $\mathrm{Lg}$ coda $\mathrm{Q}$ results are discussed in a later section.

Figures $6 a-0$ show the fits between observed and theoretical spectra for 15 recent events in our study. For each event we have plotted the spectra for each recording station used in the study, and for events recorded by two or more stations we have also plotted the station average. These plots indicate that we can obtain excellent agreement between observed and theoretical spectra in nearly all cases. In addition to the spectral fits, the plots indicate the $\mathrm{Lg} \mathrm{Q}$ value for each path and the distance of travel.

\section{Lg Coda Q}

\section{Data Processing}

Xie and Nuttli (1988) developed a stochastic model for the interpretation of single-trace Lg coda waves and an inversion method, based on that model, to determine $\mathrm{Lg}$ coda $\mathrm{Q}$ and its frequency dependence at $1 \mathrm{~Hz}$ ( $\mathrm{Q}_{0}$ and $\eta$, respectively). Advantages of their inversion method are that, with data of sufficient quality, tradeoffs between $Q_{o}$ and $\eta$ are avoided (often a problem with earlier methods) and that variances in those quantities are reduced compared to other inversion methods. Application of their stochastic model to examples of recorded ground motion showed that the randomness that occurs in Lg coda waves can be approximated by simple band-limited white Gaussian noise, a result that allows us to make quantitative estimates of variances when estimating Lg coda attenuation. 
3. The Direct Lg Phase

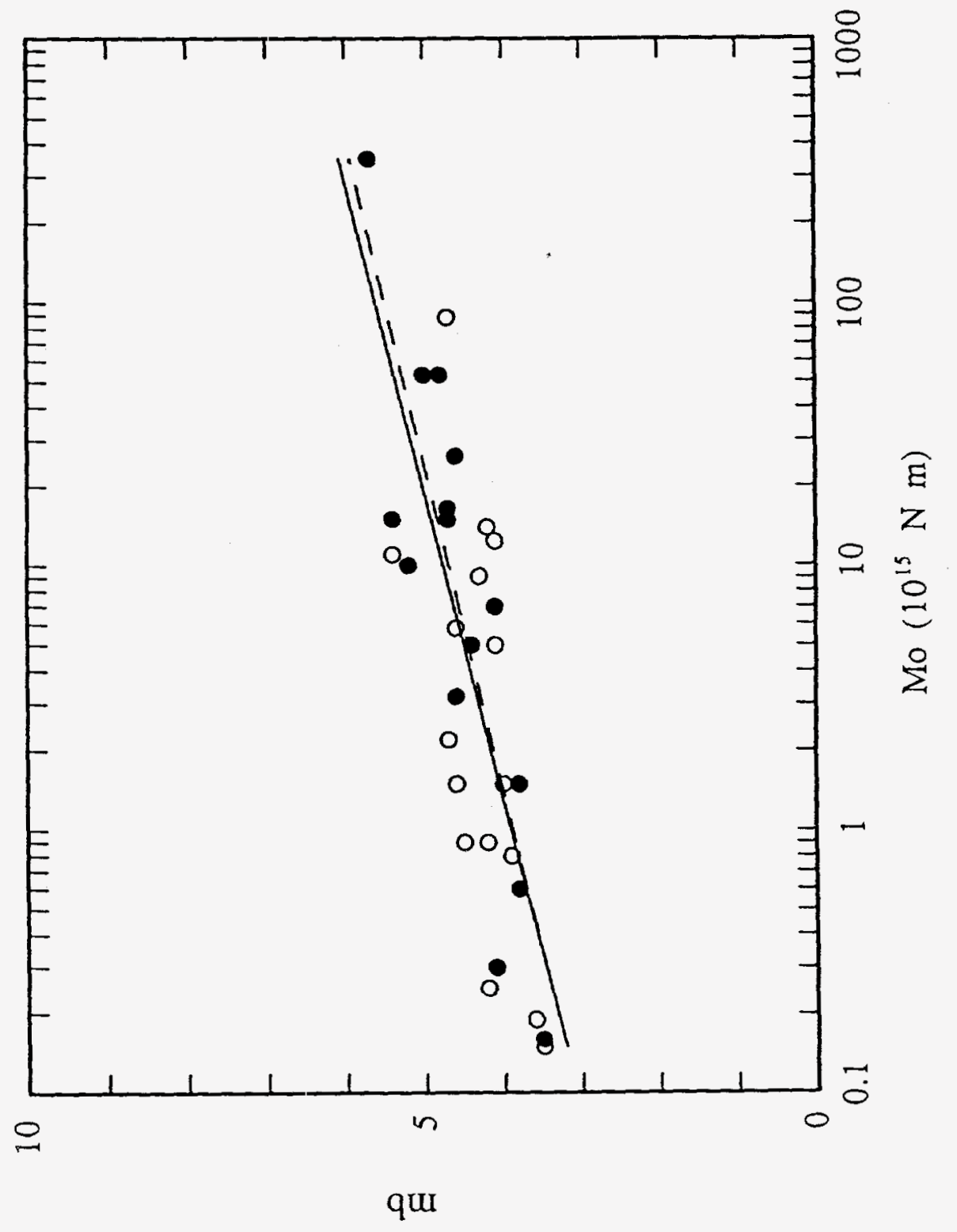

:

$\stackrel{0}{E}$

远 雚

和

点

菅志

它 葛

范

豆

远 政

过

范

兽 壳

ऽ ग

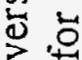

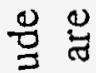

营告 
3. The Direct Lg Phase

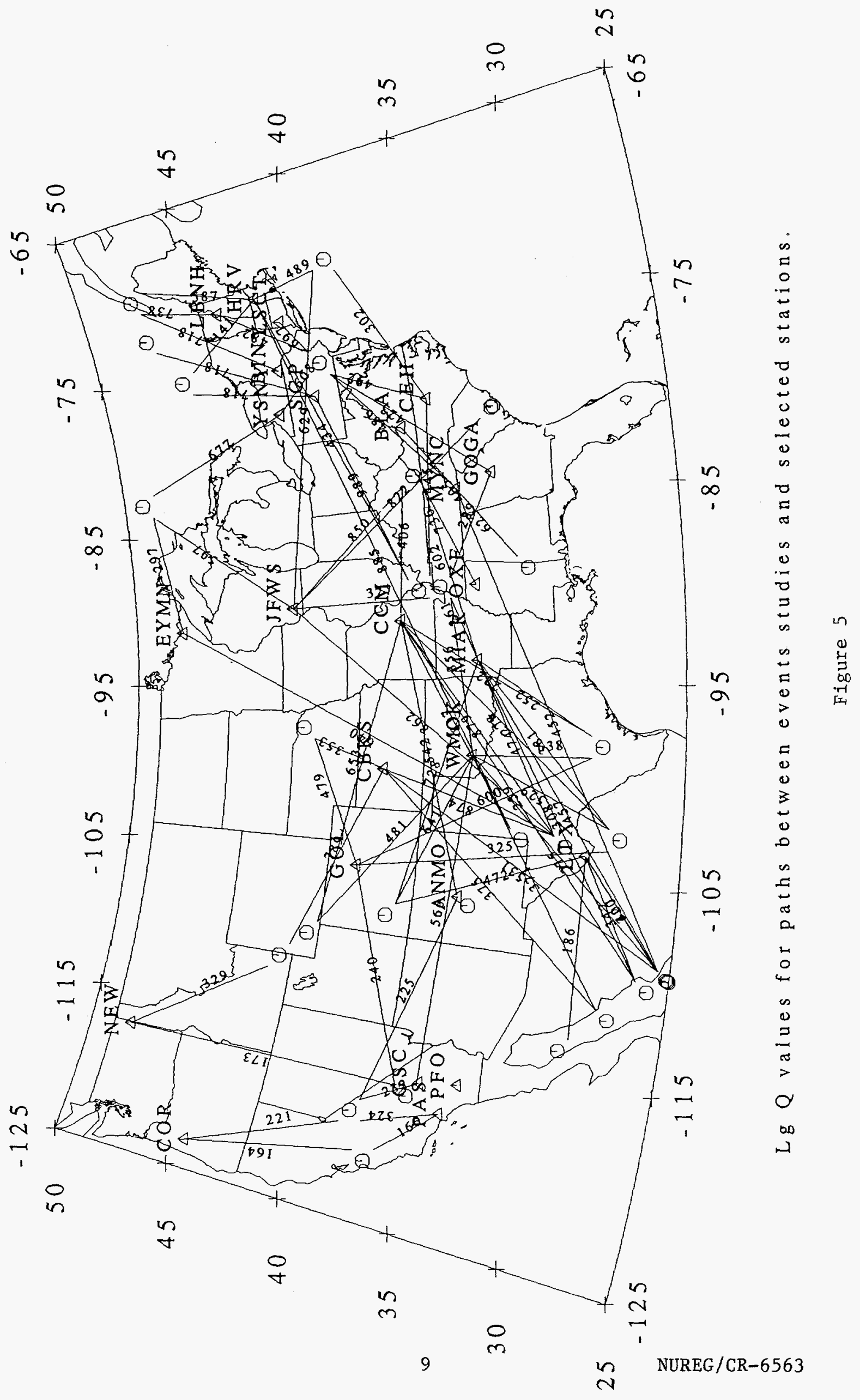


Table 2. Earthquakes used for determination of $\operatorname{Lg} Q$ values for the United States

\begin{tabular}{|c|c|c|c|c|c|c|c|c|c|c|}
\hline Event & Station & $\operatorname{Lg} Q$ & Station & $\operatorname{Lg} Q$ & Station & $\mathrm{Lg} Q$ & Station & $\operatorname{Lg} Q$ & Station & $\mathrm{Lg} \mathrm{Q}$ \\
\hline 1 & $\mathrm{CCM}$ & 545 & & & & & & & & \\
\hline 2 & PAS & 166 & COR & 166 & & & & & & \\
\hline 3 & HRV & 434 & SCP & 989 & & & & & & \\
\hline 4 & HRV & 141 & SCP & 718 & & & & & & \\
\hline 5 & $\mathrm{COR}$ & 221 & ANMO & 225 & GSC & 232 & PAS & 328 & & \\
\hline 6 & SCP & 718 & & & & & & & & \\
\hline 7 & $\mathrm{CCM}$ & 817 & HRV & 885 & & & & & & \\
\hline 8 & JFWS & 822 & & & & & & & & \\
\hline 9 & HRV & 489 & $\mathrm{CEH}$ & 302 & JFWS & 629 & & & & \\
\hline 10 & HRV & 325 & & & & & & & & \\
\hline 11 & $\mathrm{CCM}$ & 221 & GOL & 600 & MIAR & 252 & WMOK & 356 & & \\
\hline 12 & $\mathrm{CCM}$ & 259 & LTX & 342 & MAIR & 308 & & & & \\
\hline 13 & CCM & 278 & GOL & 325 & MAIR & 381 & WMOK & 529 & & \\
\hline 14 & $\mathrm{CEH}$ & 483 & LSCT & 676 & & & & & & \\
\hline 15 & $\mathrm{CEH}$ & 718 & GOGA & 464 & LBNH & 895 & MYNC & 524 & & \\
\hline 16 & LTX & 407 & & & & & & & & \\
\hline 17 & LTX & 407 & & & & & & & & \\
\hline 18 & LTX & 472 & MAIR & 728 & WMOK & 641 & & & & \\
\hline 19 & BINY & 718 & LBNH & 738 & HRV & 587 & & & & \\
\hline 20 & CBKS & 658 & $\mathrm{CCM}$ & 652 & WMOK & 356 & & & & \\
\hline 21 & $\mathrm{CCM}$ & 406 & JFWS & 850 & MIAR & 602 & OXF & 736 & & \\
\hline 22 & $\mathrm{CCM}$ & 743 & CBKS & 1.068 & JFWS & 868 & MIAR & 384 & EYMN & 964 \\
\hline 23 & $\mathrm{CEH}$ & 289 & GOGA & 289 & JFWS & 327 & MIAR & 261 & WMOK & 356 \\
\hline 24 & GOL & 240 & NEW & 173 & WMOK & 565 & & & & \\
\hline 25 & GOL & 479 & CBKS & 353 & & & & & & \\
\hline 26 & CBKS & 375 & WMOK & 371 & & & & & & \\
\hline 27 & LTX & 186 & & & & & & & & \\
\hline 28 & CBKS & 531 & MIAR & 457 & MYNC & 452 & & & & \\
\hline 29 & BLA & 405 & MYNC & 623 & & & & & & \\
\hline 30 & CBKS & 789 & NEW & 328 & & & & & & \\
\hline 31 & EYMN & 297 & JFWS & 597 & YSNY & 677 & & & & \\
\hline
\end{tabular}

The event numbers are the same as those in Table 1. 
3. The Direct Lg Phase

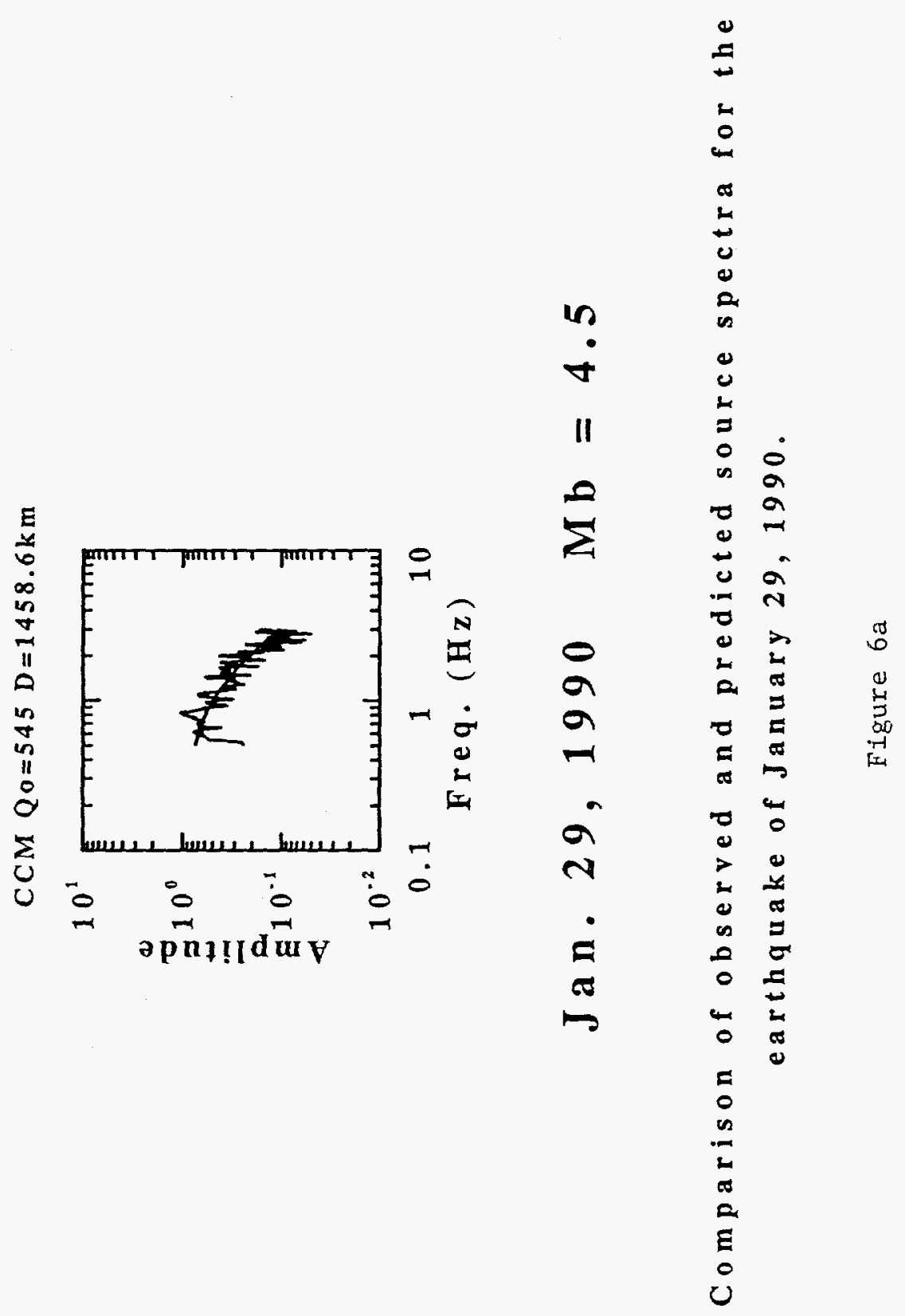



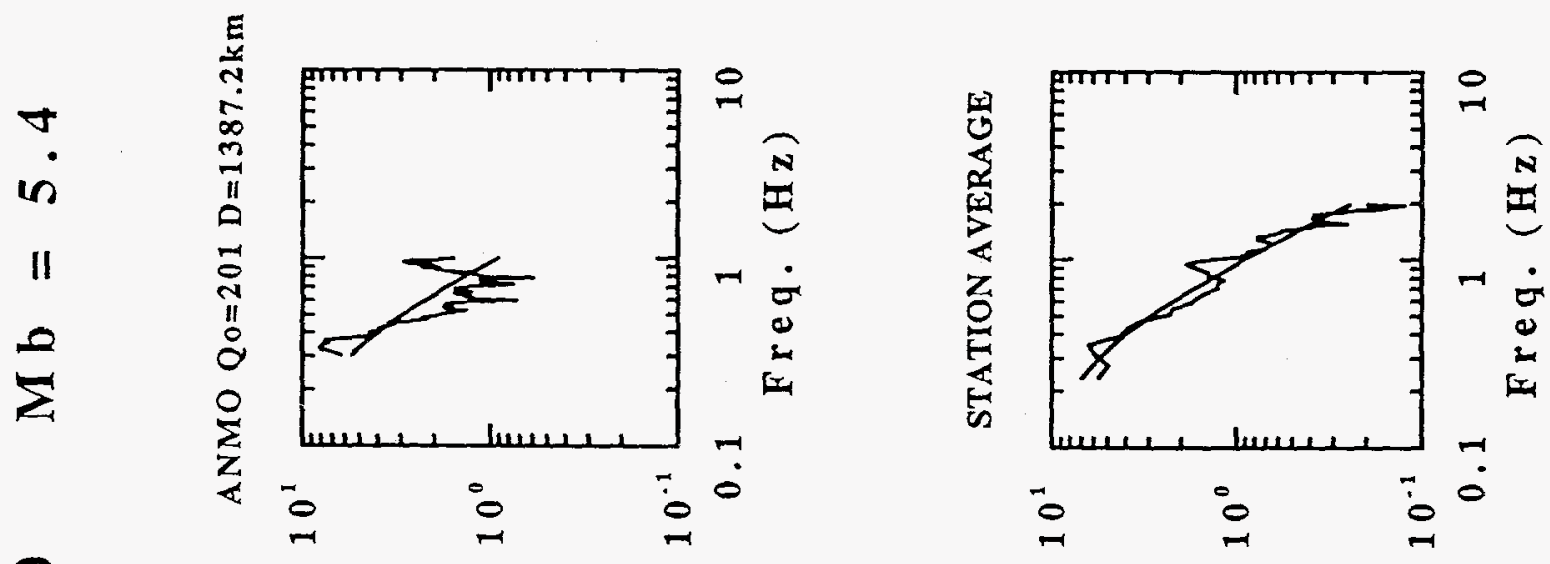

0
$a$
$a$
-1
$\infty$
-1
-
0
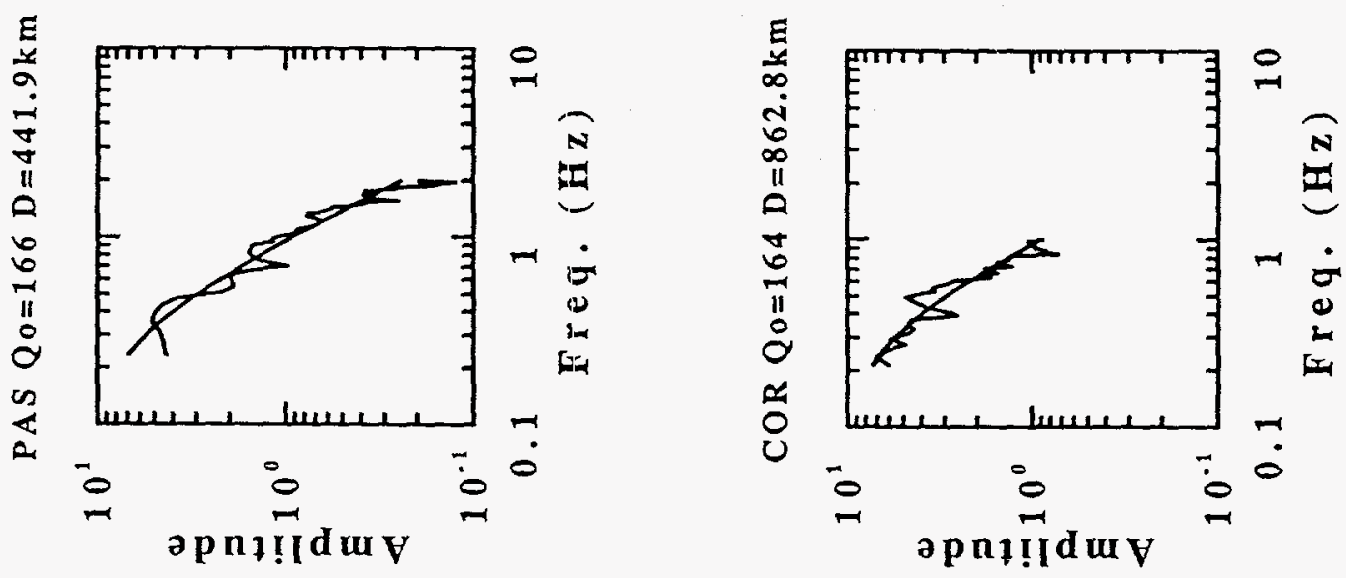
3. The Direct Lg Phase
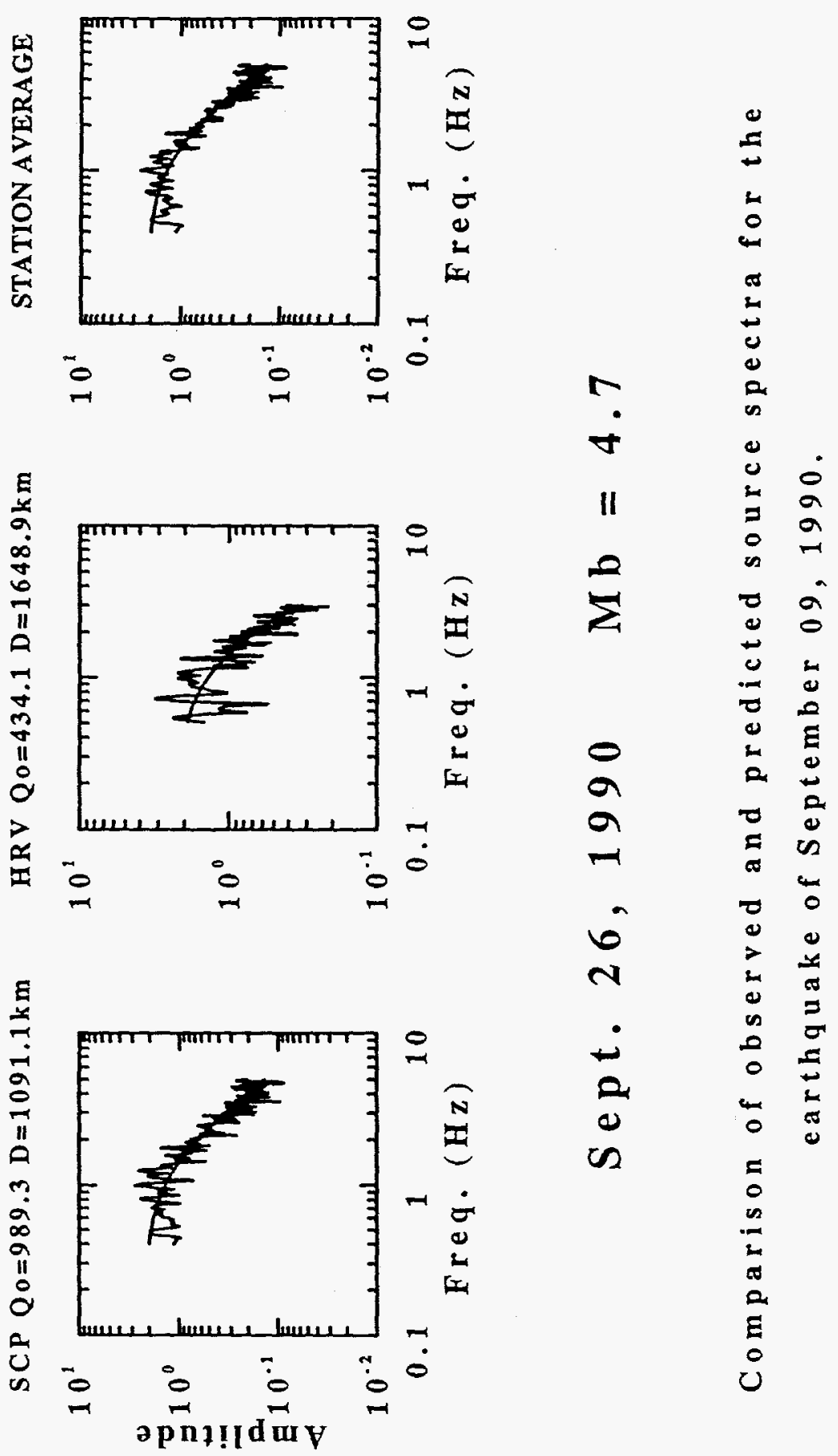
3. The Direct Lg Phase

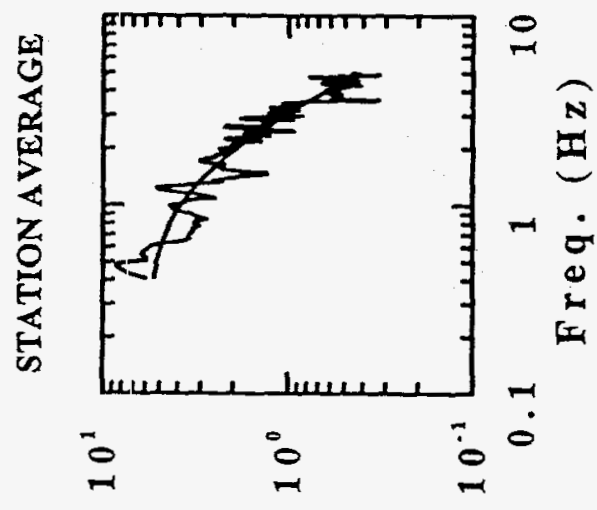


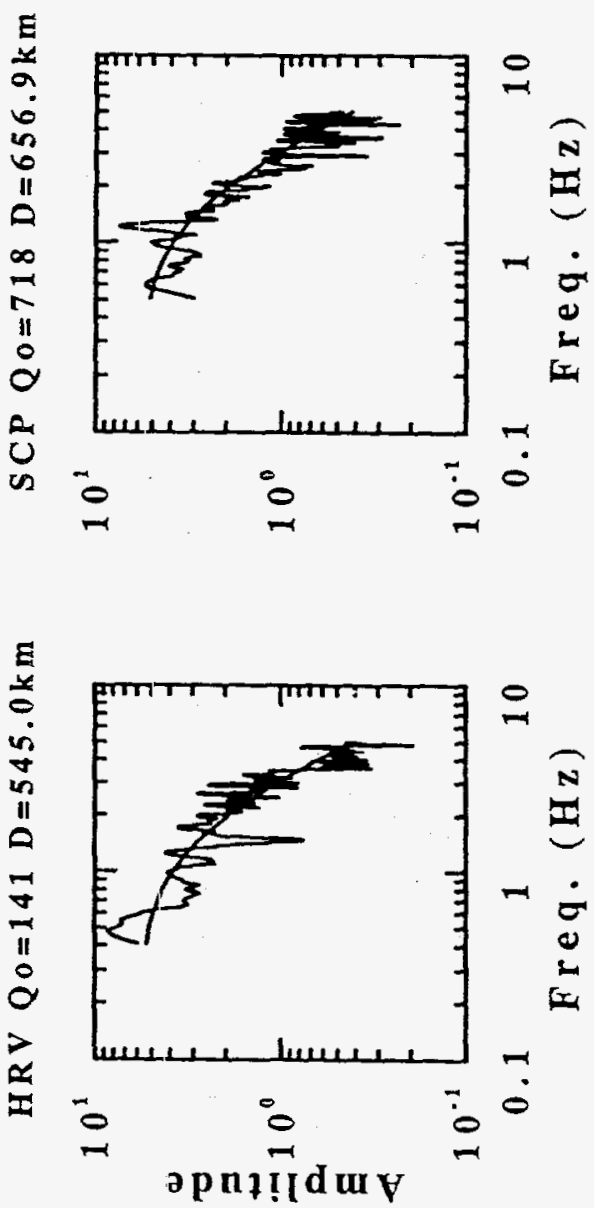

0
$a$
0
0
0
0
0

$\frac{11}{2}$

$\pi$

$\dot{0}$

$=0$

$\approx$

$\begin{array}{ll}0 & 0 \\ 0 & z \\ 2 & \pi \\ 0 & = \\ 0 & 0 \\ 0 & 5 \\ 0 & = \\ 0 & 2 \\ 0 & 0\end{array}$ 

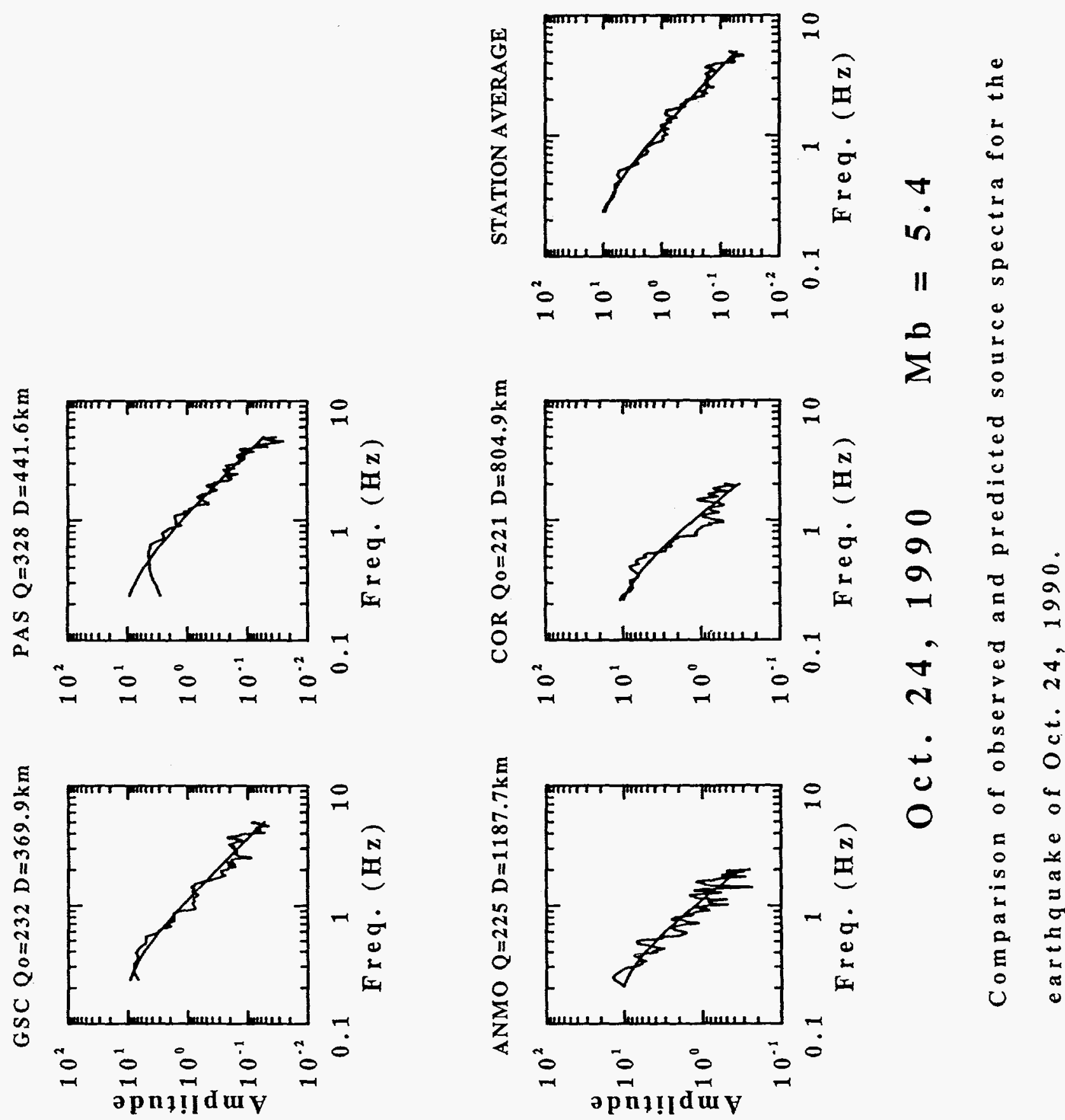
3. The Direct Lg Phase





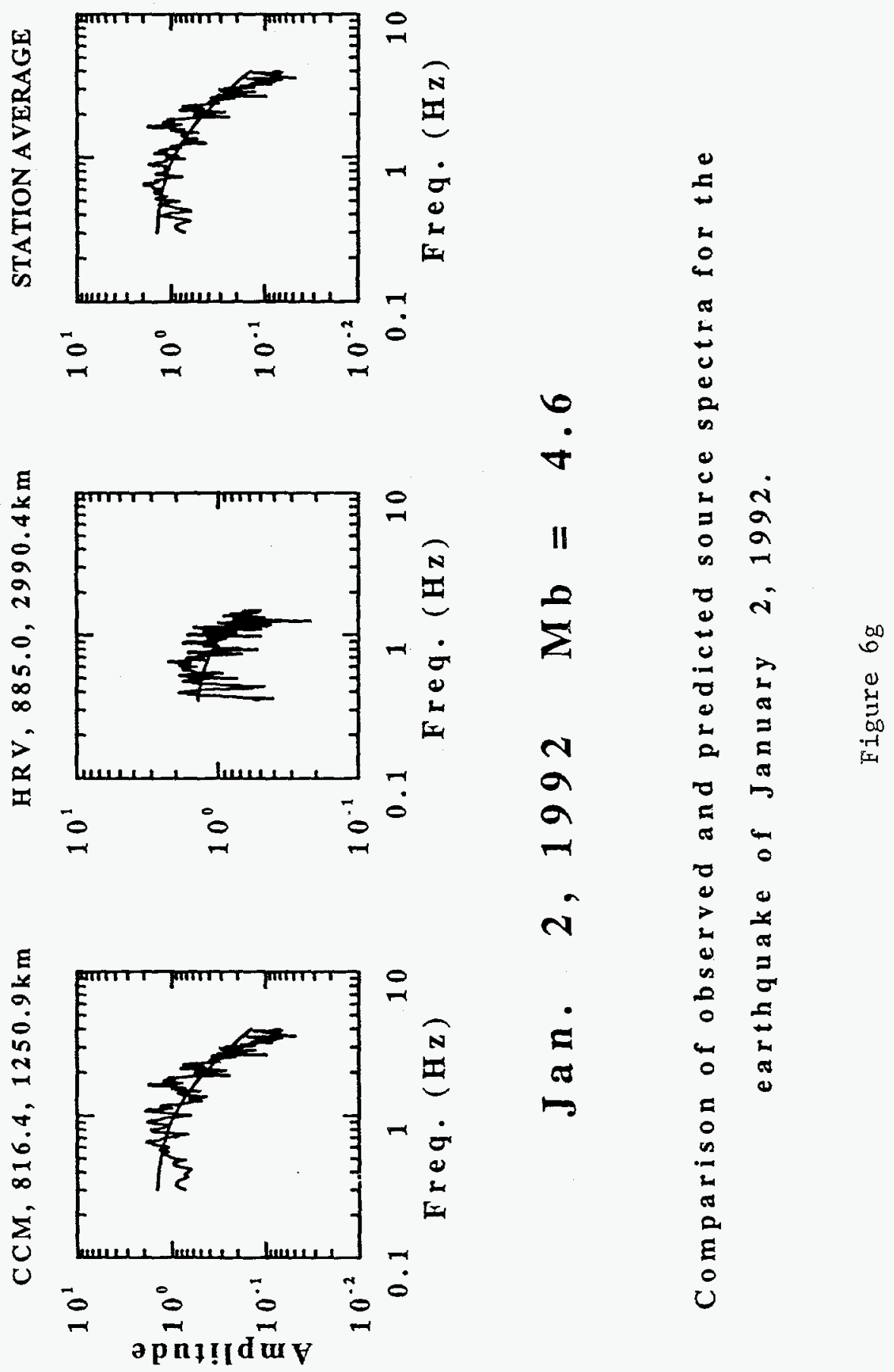

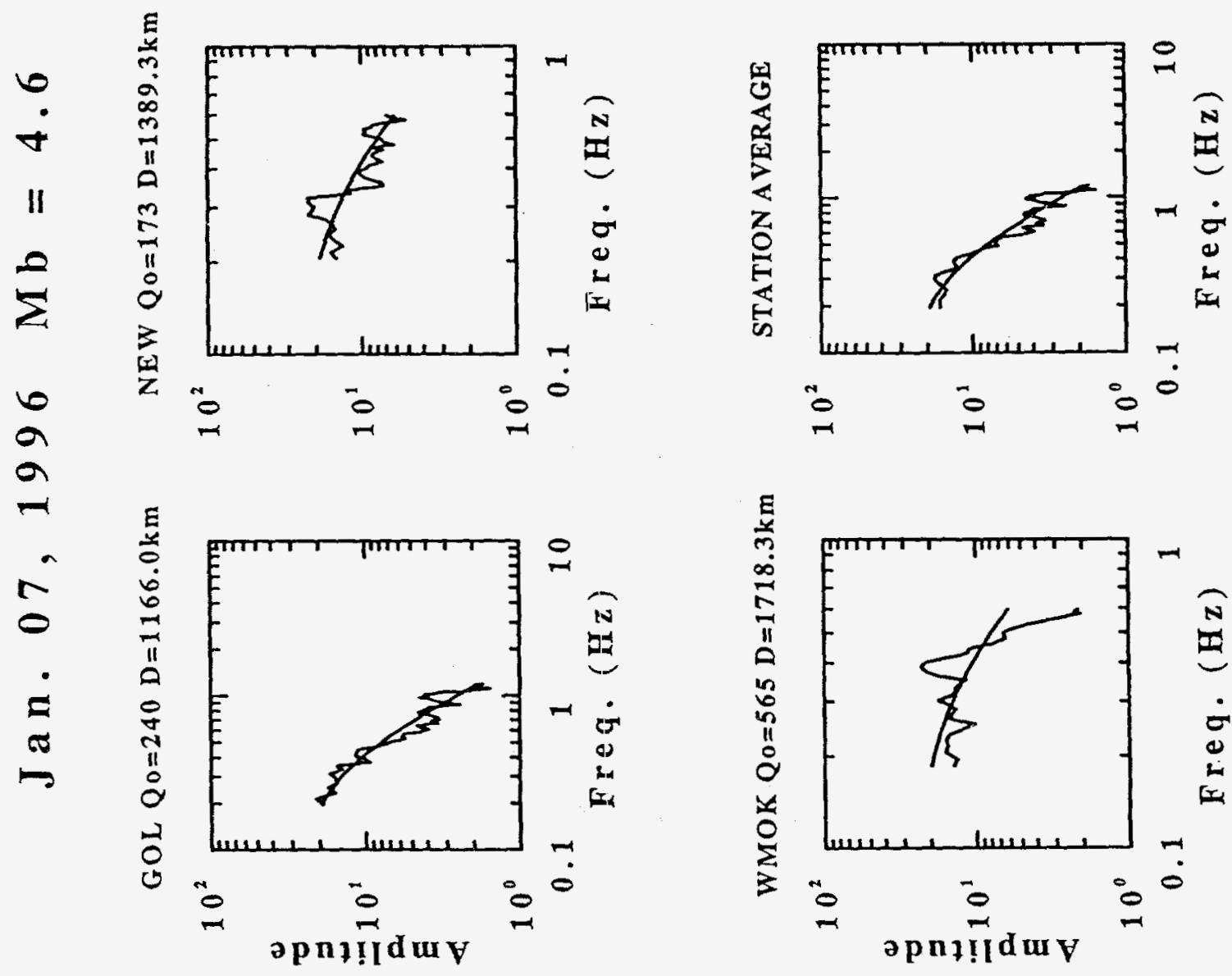


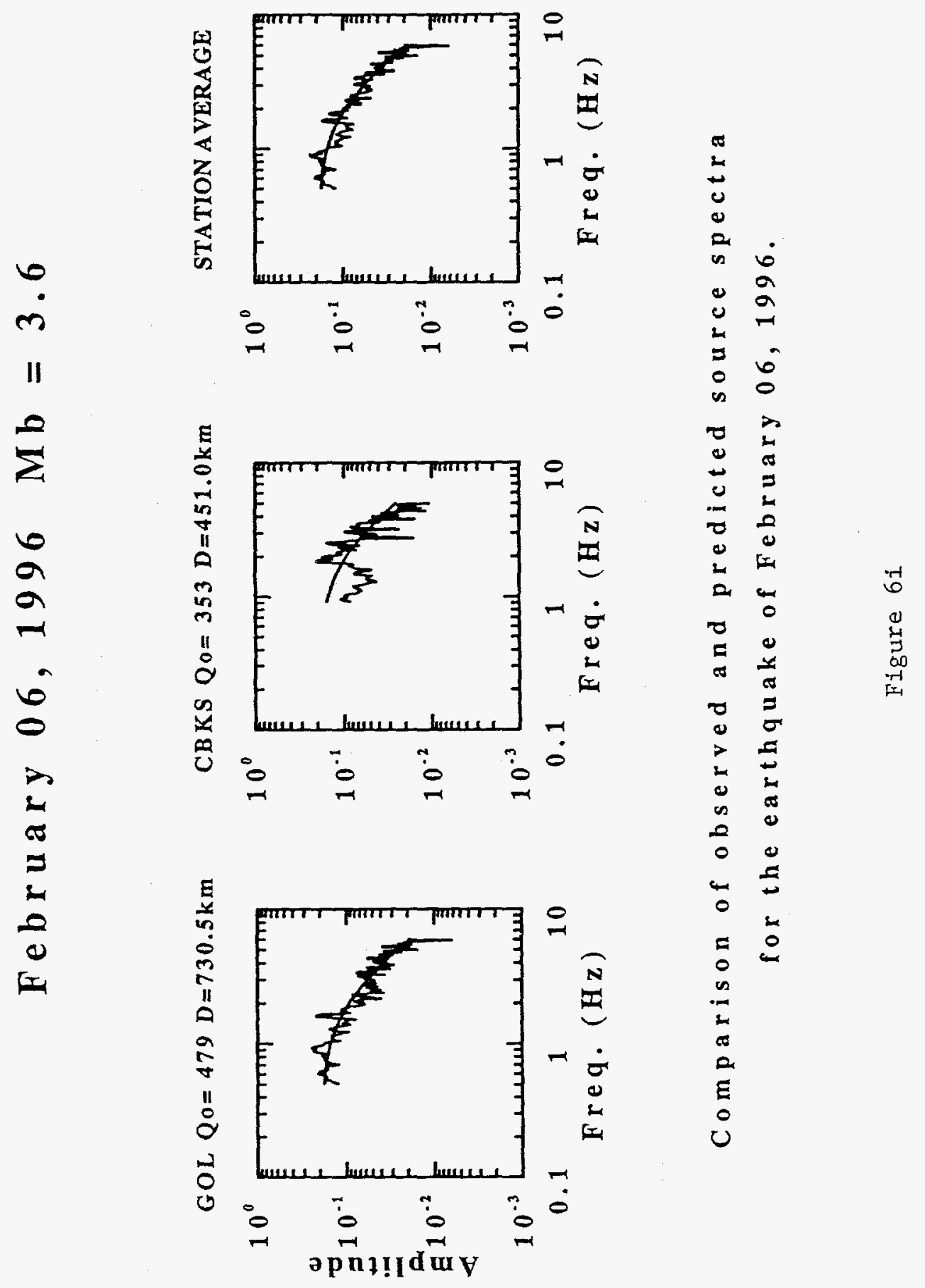


3. The Direct Lg Phase

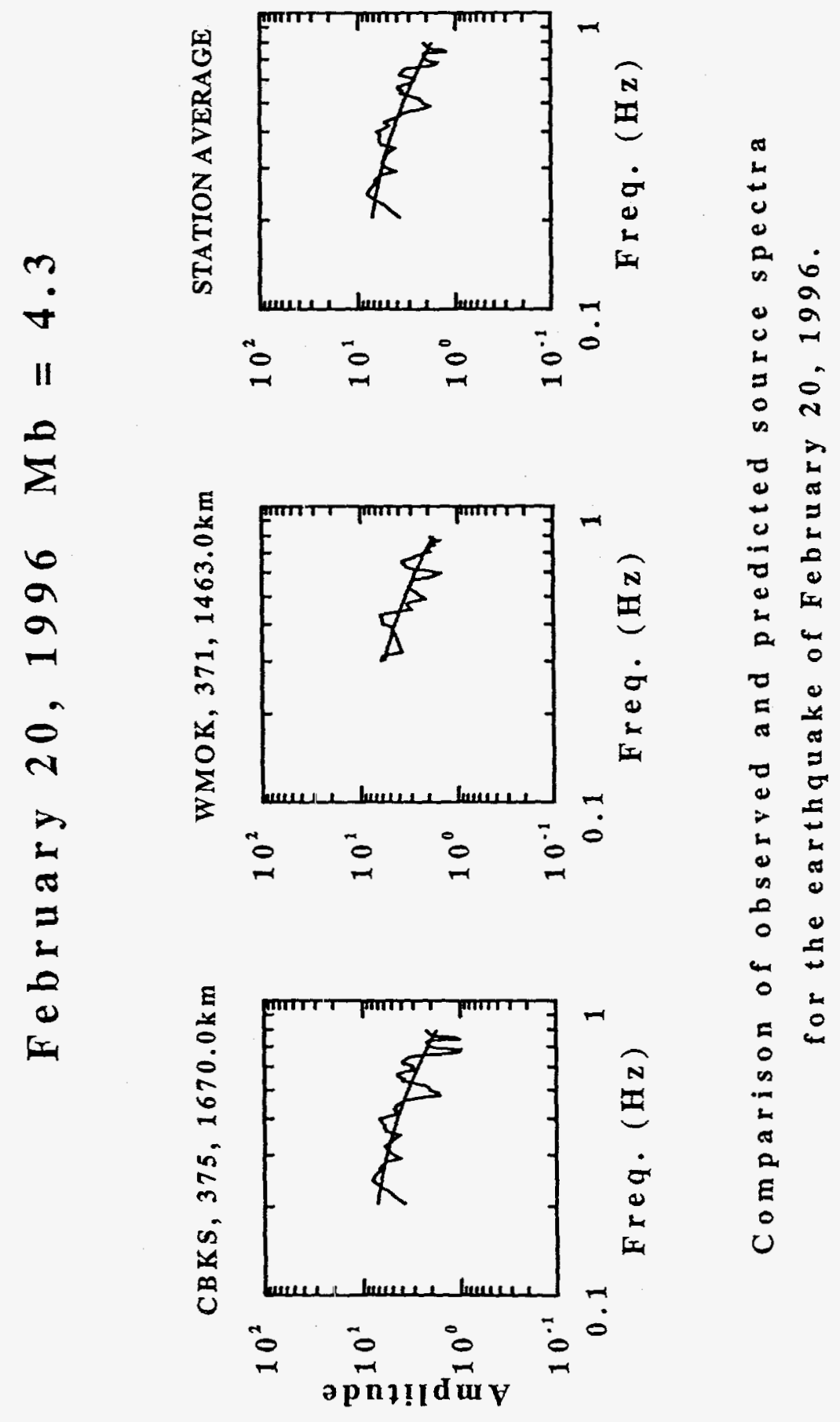

70
0
0
0
0
01
01 



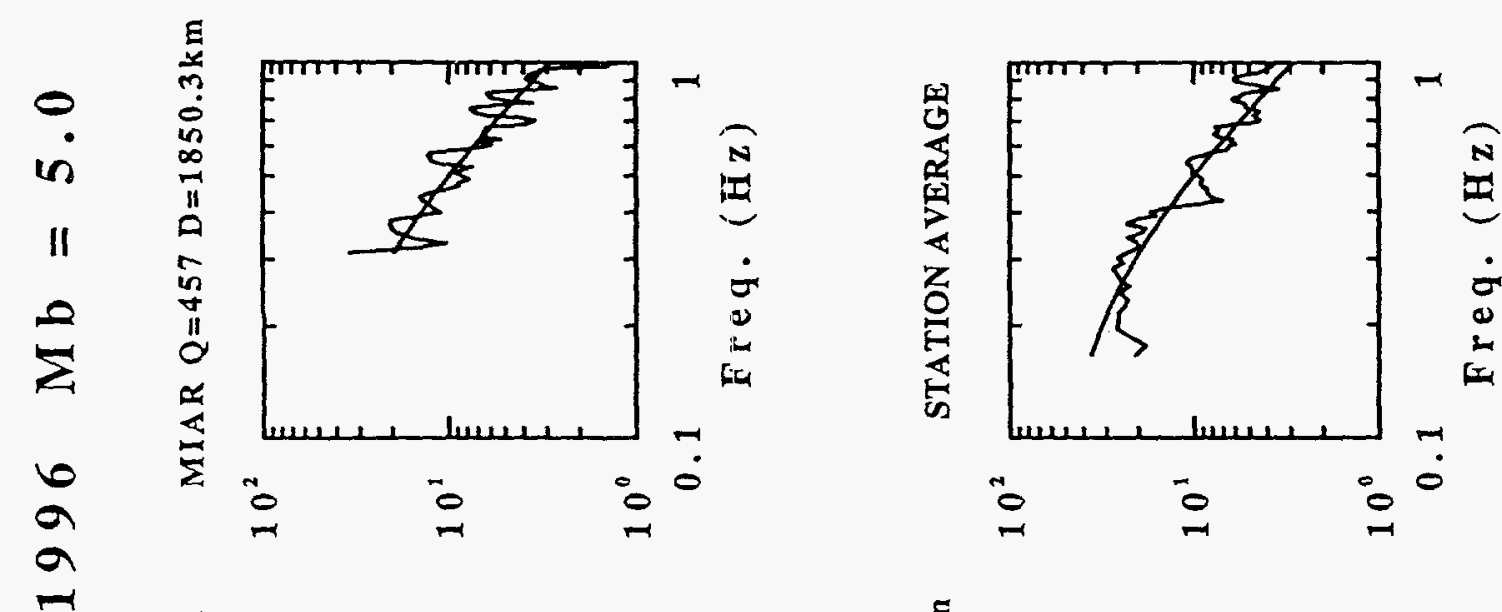

$\infty$
$\vdots$
0
0
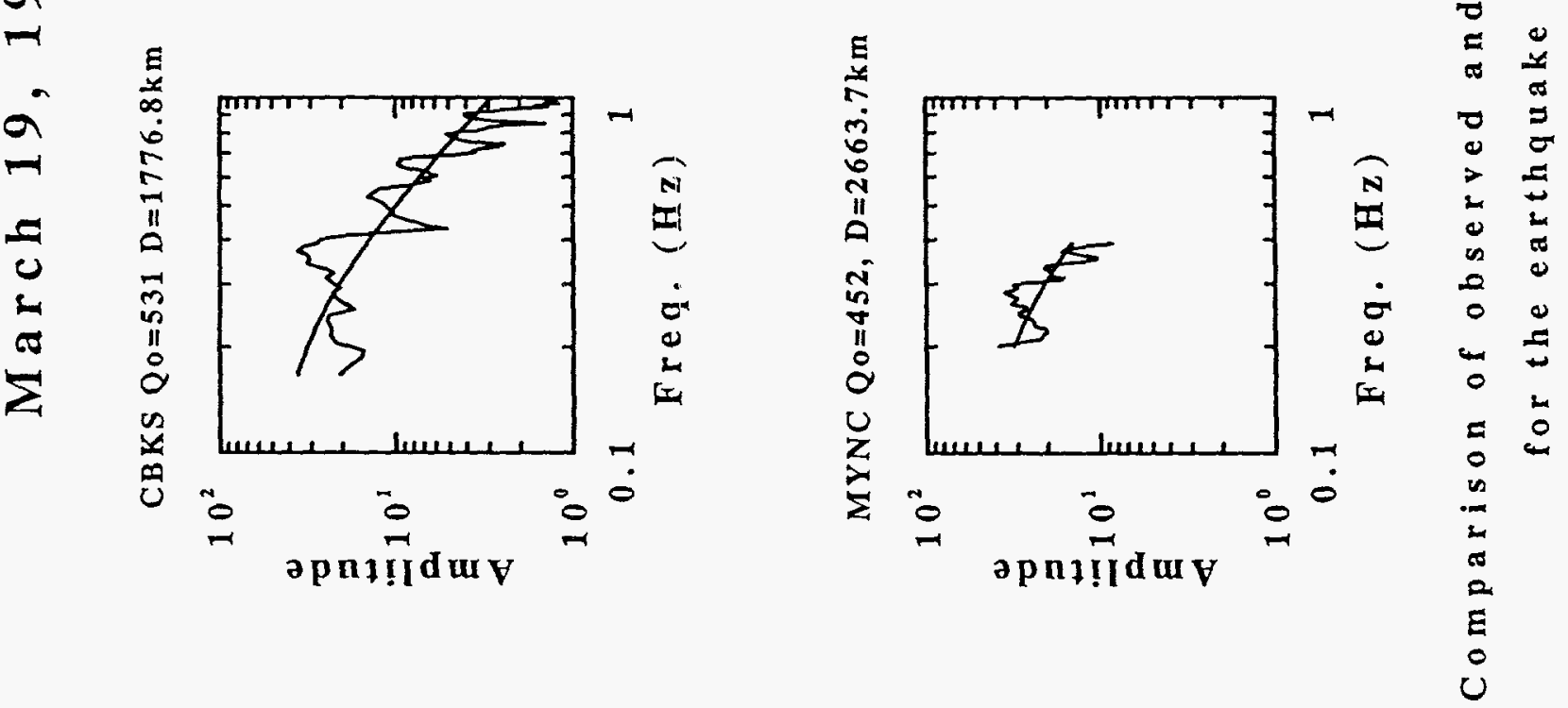
3. The Direct Lg Phase

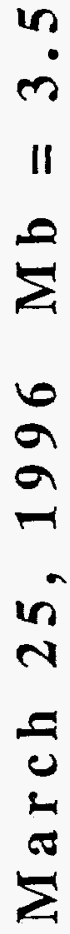


5
5
0
0
0

$a$
0
0
0
$a$
$n$
1
0
0
0
$\vdots$
0








$a$
$n$
$i$
$E$ 

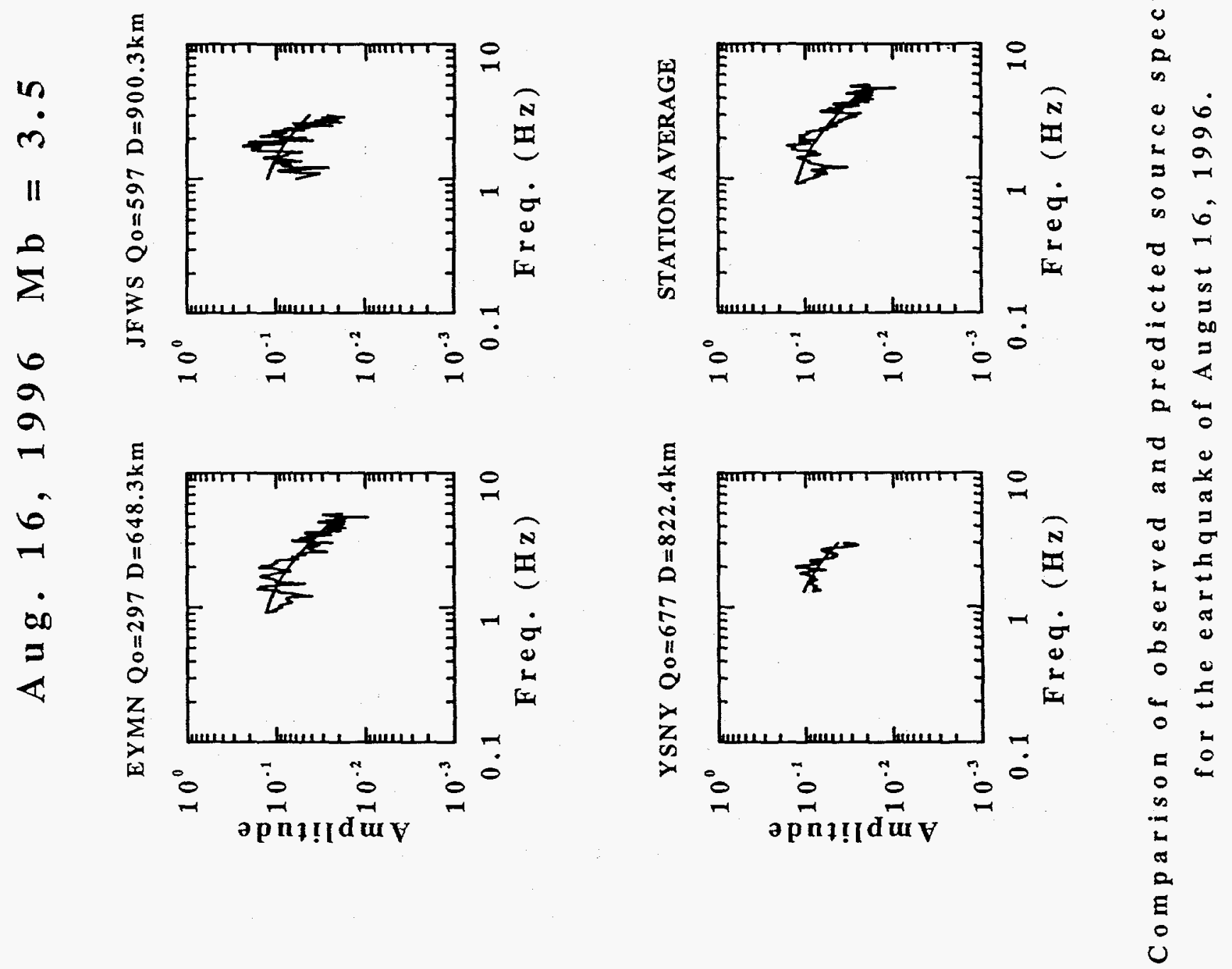


\section{Lg Coda Q}

The method for determining $\mathrm{Lg}$ coda $\mathrm{Q}$, termed the stacked spectral ratio (SSR) method, has been discussed elsewhere (Xie and Nuttli, 1988; Xie and Mitchell, 1990a); for that reason it is only summarized here. It begins by dividing the Lg coda time series into a number, $N_{W}$, of non-overlapping time windows of constant length and applying the discrete Fourier transform to each window to obtain the geometrical mean of the amplitude spectrum at each frequency. The length of each group velocity window for $\mathrm{Lg}$ is given by

$$
U_{m}=v \tau_{m}\left(1 / v_{\min }-1 / v_{\max }\right)
$$

where $\tau_{\mathrm{m}}$ is the mean lag time for the mth window, and $v, v_{\max }$, and $v_{\min }$ are, respectively, the average, maximum, and minimum group velocities of the coda wave train. Geometrical spreading is obtained using

$$
G_{m}=(2 \pi R)^{-1 / 2}\left(v^{2} \tau_{m}^{2} / R^{2}-1\right)^{-1 / 4}
$$

where $\mathrm{R}$ is the event-station distance. The SSR is defined as

$$
F_{k}=\frac{1}{M} \sum_{m=1}^{M} \frac{1}{\pi\left(\tau_{M+m}-\tau_{m}\right)} \log \left[\frac{G_{M+m} \sqrt{U_{m}}\left\langle A_{k, m}\right\rangle}{G_{m} \sqrt{U_{M+m}}\left\langle A_{k, m+M}\right\rangle}\right]
$$

where $M$ is $N_{W} / 2$ when $N_{W}$ is even and $\left(N_{W}+1\right) / 2$ when $N_{W}$ is odd. All of the quantities on the right-hand side of (7) are calculable from a coda time series.

Assuming that the frequency dependence of $\mathrm{Lg}$ coda $\mathrm{Q}$ can be expressed by a power law, $Q(f)=Q_{0} f^{\eta}$, where $Q_{0}$ and $\eta$ are, respectively, $Q$ and its frequency dependence at 1 $\mathrm{Hz}$, then

$$
\log F_{k}=(1-\eta) \log f_{k}-\log Q_{o}+\varepsilon
$$

where $\varepsilon$ represents a random error. Theoretical and observational calculations have shown that the SSR method provides a statistically stable Q estimator, with the standard error in $\mathrm{Q}_{0}$ often being an order of magnitude smaller than $\mathrm{Q}_{0}$ itself.

The SSR method was applied to all traces beginning at a group velocity of $3.15 \mathrm{~km} / \mathrm{s}$ and continuing on in time to cover a window length of 300 seconds or more, with the average length being about 450 seconds and the maximum duration being 600 seconds. We tried to minimize variations in coda length from path to path in order to avoid possible systematic biases that might be proportional to coda duration. An example of a seismic trace with its associated SSR appears in Figure 7. The best fit straight line for the spectral values in that example show that, at $1 \mathrm{~Hz}, \mathrm{Q}_{\mathrm{Lg}}^{\mathrm{c}}$ is 621 and $\eta$ (given by the slope of the line) is 0.47 . Table 3 gives $\operatorname{Lg}$ coda $Q$ values determined for individual traces in the central and eastern United States and Table 4 presents those values for the western United States.

Another possible source of bias in our determinations can arise if a large portion of the scattering ellipse overlaps oceanic regions (Xie and Mitchell, 1990b). For that reason we avoided events that occurred in oceanic regions as well as continental events for which a large fraction of the scattering ellipse overlaps an oceanic region. 
4. Lg Coda Q

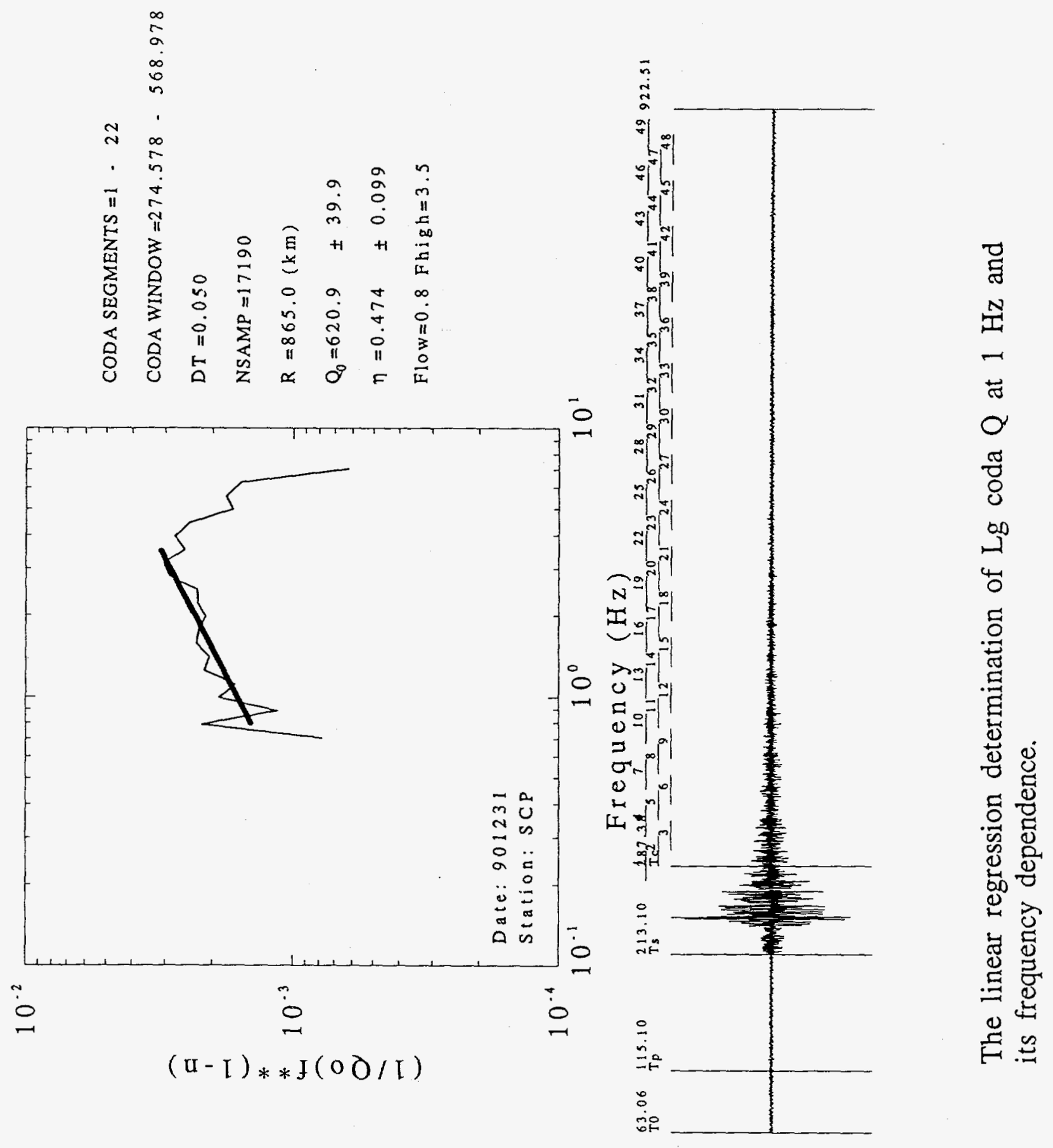


Table 3. Earthquakes and results of single-trace analysis for Lg coda $Q$ in the central and eastern United States

\begin{tabular}{|c|c|c|c|c|c|c|c|}
\hline Date & $\begin{array}{l}\text { Origin } \\
\text { (h:m:s) }\end{array}$ & $\begin{array}{c}\text { Lat } \\
\left({ }^{\circ} \mathrm{N}\right)\end{array}$ & $\begin{array}{l}\text { Lon } \\
\left({ }^{\circ} \mathrm{E}\right)\end{array}$ & $\begin{array}{l}\text { Recording } \\
\text { station }\end{array}$ & $\begin{array}{c}\text { Distance } \\
(\mathrm{km})\end{array}$ & $Q_{0}$ & $\eta$ \\
\hline 920821 & $16: 31: 35.1$ & 33.00 & -079.10 & BLA & 462.0 & $561 \pm 124$ & $0.43 \pm 0.07$ \\
\hline 921117 & 03:58:00.9 & 45.80 & -074.90 & BLA & 1057.0 & $451 \pm 84$ & $0.61 \pm 0.10$ \\
\hline 940116 & $01: 49: 16.0$ & 40.30 & -076.00 & BLA & 514.8 & $604 \pm 86$ & $0.74 \pm 0.06$ \\
\hline 940116 & $00: 42: 43.2$ & 40.33 & -076.05 & BLA & 516.5 & $455 \pm 88$ & $0.70 \pm 0.11$ \\
\hline 940925 & $00: 53: 28.0$ & 47.78 & -069.95 & BLA & 780.4 & $677 \pm 232$ & $0.57 \pm 0.09$ \\
\hline 950311 & $08: 15: 52.0$ & 37.00 & -083.20 & BLA & 243.9 & $523 \pm 52$ & $0.70 \pm 0.09$ \\
\hline 950417 & $13: 45: 57.8$ & 32.90 & -080.10 & BLA & 474.2 & $510 \pm 170$ & $0.59 \pm 0.10$ \\
\hline 950527 & $19: 51: 10.3$ & 36.20 & -089.40 & BLA & 813.2 & $619 \pm 150$ & $0.57 \pm 0.20$ \\
\hline 960325 & $14: 15: 50.4$ & 32.10 & -088.70 & BLA & 946.7 & $442 \pm 78$ & $0.52 \pm 0.10$ \\
\hline 940913 & $06: 01: 23.0$ & 38.16 & -107.98 & CBKS & 722.5 & $427 \pm 109$ & $0.96 \pm 0.06$ \\
\hline 950203 & $15: 26: 10.7$ & 41.50 & -109.60 & CBKS & 895.2 & $432 \pm 98$ & $0.50 \pm 0.09$ \\
\hline 950414 & $00: 32: 54.2$ & 30.20 & -103.30 & CBKS & 1005.8 & $425 \pm 97$ & $0.69 \pm 0.06$ \\
\hline 960206 & $15: 10: 27.6$ & 42.50 & -097.50 & CBKS & 451.0 & $413 \pm 51$ & $0.76 \pm 0.20$ \\
\hline 960220 & $14: 40: 41.9$ & 27.55 & -111.68 & CBKS & 1670.0 & $553 \pm 72$ & $0.85 \pm 0.10$ \\
\hline 960516 & 15:41:01.9 & 44.12 & -104.06 & CBKS & 1054.8 & $438 \pm 46$ & $0.67 \pm 0.10$ \\
\hline 921117 & 03:58:00.9 & 45.80 & -074.90 & CBM & 535.1 & $1102 \pm 147$ & $0.25 \pm 0.04$ \\
\hline 900129 & $13: 16: 10.6$ & 34.46 & -106.88 & CCM & 1458.6 & $603 \pm 60$ & $0.58 \pm 0.01$ \\
\hline 930409 & $00: 59: 49.5$ & 28.81 & -098.12 & CCM & 1207.5 & $749 \pm 89$ & $0.17 \pm 0.01$ \\
\hline 931205 & $00: 58: 20.2$ & 27.83 & -102.74 & $\mathrm{CCM}$ & 1559.5 & $512 \pm 34$ & $0.24 \pm 0.09$ \\
\hline 940512 & $00: 22: 23.0$ & 24.95 & -109.28 & $\mathrm{CCM}$ & 2230.4 & $582 \pm 168$ & $1.00 \pm 0.20$ \\
\hline 940925 & $00: 53: 28.0$ & 47.78 & -069.95 & $\mathrm{CCM}$ & 2036.4 & $713 \pm 162$ & $0.74 \pm 0.10$ \\
\hline 950203 & $15: 26: 10.7$ & 41.50 & -109.60 & $\mathrm{CCM}$ & 1619.0 & $511 \pm 104$ & $0.42 \pm 0.07$ \\
\hline 950311 & $08: 15: 52.0$ & 37.00 & -083.20 & CCM & 725.3 & $697 \pm 127$ & $0.74 \pm 0.10$ \\
\hline 950414 & $00: 32: 54.2$ & 30.20 & -103.30 & $\mathrm{CCM}$ & 1409.2 & $432 \pm 91$ & $0.78 \pm 0.06$ \\
\hline 950417 & $13: 45: 57.8$ & 32.90 & -080.10 & $\mathrm{CCM}$ & 1160.5 & $876 \pm 128$ & $0.51 \pm 0.10$ \\
\hline 950527 & $19: 51: 10.3$ & 36.20 & -089.40 & $\mathrm{CCM}$ & 264.2 & $765 \pm 311$ & $0.60 \pm 0.10$ \\
\hline 920102 & $11: 45: 35.8$ & 32.30 & -103.10 & $\mathrm{CCM}$ & 1250.9 & $631 \pm 28$ & $0.34 \pm 0.05$ \\
\hline 920821 & $16: 31: 55.1$ & 33.00 & -080.10 & CEH & 328.8 & $557 \pm 78$ & $0.58 \pm 0.04$ \\
\hline 920822 & $12: 20: 32.6$ & 39.10 & -070.30 & CEH & 853.6 & $636 \pm 128$ & $0.54 \pm 0.10$ \\
\hline 940116 & $01: 49: 16.0$ & 40.30 & -076.00 & $\mathrm{CEH}$ & 560.9 & $745 \pm 71$ & $0.47 \pm 0.05$ \\
\hline 950417 & $13: 45: 57.8$ & 32.90 & -080.10 & CEH & 338.6 & $643 \pm 174$ & $0.43 \pm 0.07$ \\
\hline 950527 & $19: 51: 10.3$ & 36.20 & -089.40 & CEK & 931.8 & $384 \pm 91$ & $0.49 \pm 0.10$ \\
\hline 950417 & $13: 45: 57.8$ & 32.90 & -080.10 & CVL & 577.3 & $711 \pm 153$ & $0.10 \pm 0.09$ \\
\hline 950414 & $00: 32: 54.2$ & 30.20 & -103.30 & EYMN & 2210.3 & $426 \pm 71$ & $0.74 \pm 0.07$ \\
\hline 960816 & $04: 56: 49.2$ & 49.20 & -082.90 & EYMN & 648.3 & $490 \pm 43$ & $0.59 \pm 0.09$ \\
\hline 950527 & $19: 51: 10.3$ & 36.20 & -089.40 & FVM & 220.0 & $725 \pm 180$ & $0.81 \pm 0.10$ \\
\hline 960325 & $14: 15: 50.4$ & 32.10 & -088.70 & FVM & 671.4 & $455 \pm 47$ & $0.54 \pm 0.10$ \\
\hline 940116 & $01: 49: 16.0$ & 40.30 & -076.00 & GOGA & 1013.4 & $412 \pm 121$ & $0.80 \pm 0.07$ \\
\hline 950527 & $19: 51: 10.3$ & 36.20 & -089.40 & GOGA & 625.5 & $683 \pm 190$ & $0.44 \pm 0.10$ \\
\hline 960325 & $14: 15: 50.4$ & 32.10 & -088.70 & GOGA & 511.4 & $469 \pm 48$ & $0.43 \pm 0.10$ \\
\hline 950414 & $00: 32: 54.2$ & 30.20 & -103.30 & GLD & 1068.7 & $462 \pm 112$ & $0.70 \pm 0.08$ \\
\hline 960516 & $15: 41: 01.9$ & 44.10 & -104.04 & GLD & 592.5 & $316 \pm 41$ & $0.60 \pm 0.10$ \\
\hline 931205 & $00: 58: 20.2$ & 27.80 & -102.70 & GOL & 1338.6 & $744 \pm 96$ & $0.58 \pm 0.30$ \\
\hline 940915 & $06: 01: 23.0$ & 38.20 & -107.98 & GOL & 283.9 & $427 \pm 111$ & $0.64 \pm 0.06$ \\
\hline 950203 & $15: 26: 10.7$ & 41.50 & -109.60 & GOL & 414.3 & $640 \pm 117$ & $0.86 \pm 0.10$ \\
\hline 960107 & $14: 32: 52.1$ & 35.80 & -117.65 & GOL & 1166.0 & $528 \pm 39$ & $0.52 \div 0.10$ \\
\hline 950527 & $19: 51: 10.3$ & 36.20 & -089.40 & HBF & 904.6 & $458 \pm 184$ & $0.62 \pm 0.10$ \\
\hline 900926 & $13: 18: 51.3$ & 37.20 & -089.58 & HRV & 1648.9 & $534 \pm 111$ & $0.54 \pm 0.20$ \\
\hline 901019 & $07: 01: 57.4$ & 46.47 & -075.59 & HRV & 545.0 & $711 \pm 50$ & $0.31 \pm 0.07$ \\
\hline 920102 & $11: 45: 35.8$ & 32.33 & -103.10 & HRV & 2990.4 & $443 \pm 33$ & $0.80 \pm 0.10$ \\
\hline 940116 & $01: 49: 16.0$ & 40.30 & -076.00 & HRV & 445.7 & $655 \pm 130$ & $0.56 \pm 0.07$ \\
\hline 950527 & $19: 51: 10.4$ & 36.20 & -089.40 & JFWS & 752.3 & $788 \pm 190$ & $0.67 \pm 0.10$ \\
\hline 940925 & $00: 53: 28.0$ & 47.78 & -069.95 & LBNH & 421.1 & $723 \pm 192$ & $0.54 \pm 0.05$ \\
\hline 940116 & $01: 49: 16.0$ & 40.35 & -076.05 & LBNH & 551.1 & $1305 \pm 170$ & $0.20 \pm 0.06$ \\
\hline 950417 & $13: 45: 57.8$ & 32.9 & -80.100 & LBNH & 1444.9 & $539 \pm 100$ & $0.95 \pm 0.09$ \\
\hline 940116 & $01: 49: 16.0$ & 40.30 & -076.00 & LSCT & 280.1 & $642 \pm 84$ & $0.52 \pm 0.04$ \\
\hline 940116 & $00: 42: 43.2$ & 40.35 & -076.04 & MCWV & 278.2 & $682 \pm 192$ & $0.80 \pm 0.10$ \\
\hline 940116 & $01: 49: 16.0$ & 40.30 & -076.00 & MCWV & 333.8 & $729 \pm 60$ & $0.40 \pm 0.03$ \\
\hline 931205 & $00: 58: 20.2$ & 27.83 & -102.74 & MIAR & 1146.2 & $466 \pm 28$ & $0.51 \pm 0.09$ \\
\hline 940913 & $06: 01: 23.0$ & 38.16 & -107.98 & MIAR & 1351.8 & $600 \pm 96$ & $0.60 \pm 0.06$ \\
\hline 950311 & $08: 15: 52.0$ & 37.00 & -083.20 & MIAR & 980.0 & $519 \pm 187$ & $0.60 \pm 0.10$ \\
\hline 950414 & $00: 32: 54.2$ & 30.20 & -103.30 & MLAR & 1033.3 & $412 \pm 49$ & $0.20 \pm 0.10$ \\
\hline 950527 & $19: 51: 10.3$ & 36.20 & -089.40 & MLAR & 417.4 & $618 \pm 181$ & $0.79 \pm 0.10$ \\
\hline 960325 & $14: 15: 50.4$ & 32.10 & -088.70 & JMYNK & 537.4 & $460 \pm 26$ & $0.53 \pm 0.06$ \\
\hline
\end{tabular}


Table 3. (continued)

\begin{tabular}{|c|c|c|c|c|c|c|c|}
\hline Date & $\begin{array}{l}\text { Origin } \\
\text { (h:m:s) }\end{array}$ & $\begin{array}{l}\text { Lat } \\
(0 \mathrm{~N})\end{array}$ & $\begin{array}{c}\text { Lon } \\
(\mathrm{O} \mathrm{E})\end{array}$ & $\begin{array}{l}\text { Recording } \\
\text { station }\end{array}$ & $\begin{array}{c}\text { Distance } \\
(\mathbf{k m})\end{array}$ & $\mathbf{Q}_{0}$ & $\eta$ \\
\hline 940116 & $01: 49: 16.0$ & 40.35 & -076.04 & MYNC & 921.0 & $773 \pm 150$ & $0.30 \pm 0.09$ \\
\hline 950311 & $08: 15: 52.0$ & 37.00 & -083.20 & OXF & 629.9 & $541 \pm 104$ & $0.45 \pm 0.10$ \\
\hline 931205 & $00: 58: 20.0$ & 27.83 & -102.70 & OXF & 1468.5 & $594 \pm 65$ & $0.66 \pm 0.10$ \\
\hline 950417 & $13: 45: 57.8$ & 32.90 & -080.10 & PRM & 247.7 & $650 \pm 131$ & $0.39 \pm 0.07$ \\
\hline 940116 & $01: 49: 16.0$ & 40.35 & -076.04 & RSNY & 484.6 & $765 \pm 103$ & $0.43 \pm 0.05$ \\
\hline 940925 & $06: 01: 23.0$ & 47.78 & -069.95 & RSNY & 503.0 & $730 \pm 162$ & $0.69 \pm 0.09$ \\
\hline 950311 & 08:15:52.0 & $\mathbf{3 7 . 0 0}$ & -083.20 & RSNY & 1110.6 & $637 \pm 150$ & $0.25 \pm 0.10$ \\
\hline 950527 & $19: 15: 52.0$ & 36.20 & -089.40 & RSNY & 1563.0 & $566 \pm 100$ & $0.49 \pm 0.09$ \\
\hline 950527 & $19: 51: 10.3$ & 36.20 & -089.40 & SGS & 881.0 & $402 \pm 195$ & $0.88 \pm 0.10$ \\
\hline 930409 & $00: 59: 49.5$ & 28.81 & -098.12 & WMOK & 660.0 & $505 \pm 33$ & $0.15 \pm 0.01$ \\
\hline 931205 & $00: 58: 20.2$ & 27.83 & -102.74 & WMOK & 853.0 & $282 \pm 07$ & $0.79 \pm 0.03$ \\
\hline 940913 & $06: 01: 23.0$ & 38.16 & -107.98 & WMOK & 906.7 & $554 \pm 138$ & $0.69 \pm 0.10$ \\
\hline 950414 & $00: 32: 54.2$ & 30.20 & -103.30 & WMOK & 656.0 & $422 \pm 54$ & $0.59 \pm 0.03$ \\
\hline 950527 & $19: 51: 10.3$ & 36.20 & -089.40 & WMOK & 863.3 & $727 \pm 175$ & $0.50 \pm 0.10$ \\
\hline 960319 & $15: 31: 36.4$ & 25.00 & -109.30 & WMOK & 1481.6 & $463 \pm 18$ & $0.78 \pm 0.04$ \\
\hline 960220 & $14: 40: 41.9$ & 27.55 & -111.68 & WMOK & 1463.0 & $349 \pm 40$ & $0.68 \pm 0.10$ \\
\hline 960107 & 14:32:53.1 & 35.77 & -117.65 & WMOK & 1718.3 & $897 \pm 50$ & $0.80 \pm 0.06$ \\
\hline 940116 & $01: 49: 16.0$ & 40.30 & -076.00 & YSNY & 317.1 & $947 \pm 223$ & $0.30 \pm 0.10$ \\
\hline 960325 & $14: 15: 50.4$ & 32.10 & -088.70 & JSC & 734.5 & $313 \pm 14$ & $0.80 \pm 0.05$ \\
\hline 960325 & $14: 15: 50.4$ & 32.10 & -088.70 & LHS & 780.7 & $310 \pm 31$ & $0.76 \pm 0.10$ \\
\hline 920102 & $11: 45: 35.8$ & 32.34 & -103.10 & SCP & 2435.4 & $470 \pm 36$ & $0.40 \pm 0.10$ \\
\hline 900926 & $13: 18: 51.3$ & 37.20 & -089.58 & SCP & 1091.1 & $647 \pm 25$ & $0.63 \pm 0.06$ \\
\hline 901019 & $07: 01: 57.4$ & 47.58 & -072.56 & SCP & 656.9 & $831 \pm 16$ & $0.30 \pm 0.03$ \\
\hline 901231 & $03: 53: 58.3$ & 47.58 & -072.56 & SCP & 865.0 & $620 \pm 39$ & $0.47 \pm 0.09$ \\
\hline 931205 & $00: 58: 20.2$ & 27.83 & -102.74 & RSSD & 1811.2 & $425 \pm 24$ & $0.79 \pm 0.09$ \\
\hline 940913 & $06: 01: 23.0$ & 38.16 & -107.98 & RSSD & 740.9 & $430 \pm 84$ & $0.73 \pm 0.06$ \\
\hline 960107 & $14: 32: 53.1$ & 35.77 & -117.65 & RSSD & 1485.0 & $436 \pm 85$ & $0.90 \pm 0.10$ \\
\hline 960516 & $15: 41: 01.9$ & 44.12 & -104.04 & RSSD & 605.5 & $412 \pm 27$ & $0.70 \pm 0.10$ \\
\hline 960516 & $15: 41: 01.9$ & 44.12 & -104.04 & NEW & 782.6 & $439 \pm 44$ & $0.64 \pm 0.10$ \\
\hline 930602 & 02:08:32.7 & 25.95 & -109.99 & LTX & 727.7 & $288 \pm 16$ & $0.49 \pm 0.07$ \\
\hline 940512 & $00: 22: 23.0$ & 24.90 & -109.28 & LTX & 730.4 & $317 \pm 75$ & $0.74 \pm 0.07$ \\
\hline 940512 & $01: 14: 07.7$ & 24.68 & -109.10 & LTX & 730.0 & $305 \pm 65$ & $0.50 \pm 0.07$ \\
\hline 940925 & $00: 53: 28.0$ & 47.78 & -069.95 & BINY & 781.7 & $677 \pm 100$ & $0.57 \pm 0.09$ \\
\hline
\end{tabular}

The origin times and locations are from the U.S. Geological Survey's Preliminary Determination of Epicenters; The $Q_{0}$ and $\eta$ values with standard errors for each path are obtained in this study. 
Table 4. Earthquakes and results of single-trace analysis for Lg coda $Q$ in the western United States

\begin{tabular}{|c|c|c|c|c|c|c|c|}
\hline Date & $\begin{array}{l}\text { Origin } \\
(\mathrm{h}: \mathrm{m}: \mathrm{s})\end{array}$ & $\begin{array}{l}\text { Lat } \\
\left({ }^{\circ} \mathrm{N}\right)\end{array}$ & $\begin{array}{l}\text { Lon } \\
(\mathrm{O} E)\end{array}$ & $\begin{array}{l}\text { Recording } \\
\text { station }\end{array}$ & $\begin{array}{c}\text { Distance } \\
(\mathbf{k m})\end{array}$ & $\mathrm{Q}_{0}$ & $n$ \\
\hline 890627 & $15: 30: 00.1$ & 37.28 & -116.36 & ELK & 397.0 & $225 \pm 31$ & $0.46 \pm 0.03$ \\
\hline 890622 & 21:15:00.0 & 37.28 & -116.41 & ELK & 397.5 & $234 \pm 62$ & $0.30 \pm 0.08$ \\
\hline 891031 & $59: 30: 00.0$ & 37.26 & -116.49 & ELK & 401.4 & $221 \pm 23$ & $0.44 \pm 0.03$ \\
\hline 890309 & $14: 05: 00.1$ & 37.14 & -116.07 & ELK & 401.7 & $235 \pm 34$ & $0.51 \pm 0.05$ \\
\hline 890210 & $20: 06: 00.0$ & 37.08 & -116.00 & ELK & 412.9 & $246 \pm 29$ & $0.45 \pm 0.04$ \\
\hline 900725 & $15: 00: 00.0$ & 37.21 & -116.21 & ELK & 401.7 & $224 \pm 42$ & $0.31 \pm 0.06$ \\
\hline 900613 & $16: 00: 00.0$ & 37.26 & -116.42 & ELK & 400.0 & $239 \pm 20$ & $0.38 \pm 0.03$ \\
\hline 890627 & $15: 30: 00.1$ & 37.28 & -116.35 & KNB & 314.7 & $280 \pm 38$ & $0.58 \pm 0.07$ \\
\hline 890622 & $21: 15: 00.0$ & 37.28 & -116.41 & KNB & 320.1 & $297 \pm 58$ & $0.51 \pm 0.06$ \\
\hline 891031 & $15: 30: 00.0$ & 37.26 & -116.49 & KNB & 327.0 & $254 \pm 29$ & $0.60 \pm 0.06$ \\
\hline 890309 & $14: 05: 00.1$ & 37.14 & -116.07 & $\mathrm{KNB}$ & 288.4 & $242 \pm 35$ & $0.26 \pm 0.08$ \\
\hline 890210 & $20: 06: 00.0$ & 37.08 & -116.00 & KNB & 282.4 & $283 \pm 56$ & $0.42 \pm 0.06$ \\
\hline 900613 & $.16: 00: 00.0$ & 37.26 & -116.42 & $\mathrm{KNB}$ & 320.8 & $287 \pm 48$ & $0.45 \pm 0.05$ \\
\hline 900310 & $16: 00: 00.0$ & 37.11 & -116.06 & $\mathrm{KNB}$ & 288.1 & $259 \pm 45$ & $0.46 \pm 0.05$ \\
\hline 900725 & $15: 00: 00.0$ & 37.21 & -116.21 & KNNB & 301.8 & $275 \pm 33$ & $0.41 \pm 0.03$ \\
\hline 910404 & $18: 59: 59.9$ & 37.29 & -116.31 & KNB & 311.3 & $276 \pm 38$ & $0.51 \pm 0.04$ \\
\hline 920326 & $16: 30: 00.0$ & 37.27 & -116.36 & KNB & 315.5 & $266 \pm 24$ & $0.38 \pm 0.03$ \\
\hline 890627 & $15: 30: 00.1$ & 37.28 & -116.35 & MNV & 204.2 & $200 \pm 18$ & $0.30 \pm 0.04$ \\
\hline 890622 & $21: 15: 00.0$ & 37.28 & -116.41 & MNV & 199.6 & $268 \pm 48$ & $0.46 \pm 0.05$ \\
\hline 891031 & $59: 30: 00.0$ & 37.26 & -116.49 & MNV & 195.7 & $230 \pm 23$ & $0.40 \pm 0.04$ \\
\hline 890309 & $14: 05: 00.1$ & 37.14 & -116.07 & MNV & 226.9 & $243 \pm 39$ & $0.56 \pm 0.05$ \\
\hline 900725 & $15: 00: 00.0$ & 37.21 & -116.21 & MNV & 208.6 & $233 \pm 42$ & $0.35 \pm 0.05$ \\
\hline 900613 & $16: 00: 00.0$ & 37.26 & -116.42 & MNV & 200.5 & $236 \pm 26$ & $0.40 \pm 0.03$ \\
\hline 900310 & $16: 00: 00.0$ & 37.11 & -116.06 & MNV & 235.0 & $228 \pm 32$ & $0.40 \pm 0.04$ \\
\hline 910404 & $19: 00: 00.0$ & 37.29 & -116.31 & MNV & 205.5 & $224 \pm 27$ & $0.35 \pm 0.04$ \\
\hline 891031 & $59: 29: 59.9$ & 37.26 & -116.49 & LAC & 318.9 & $241 \pm 34$ & $0.50 \pm 0.05$ \\
\hline 900613 & $16: 00: 00.0$ & 37.26 & -116.42 & LAC & 318.7 & $257 \pm 31$ & $0.59 \pm 0.04$ \\
\hline 900310 & $16: 00: 00.0$ & 37.11 & -116.06 & LAC & 303.8 & $265 \pm 30$ & $0.38 \pm 0.03$ \\
\hline 900725 & $15: 00: 00.0$ & 37.21 & -116.21 & LAC & 313.1 & $245 \pm 45$ & $0.53 \pm 0.06$ \\
\hline 910404 & $18: 59: 59.9$ & 37.29 & -116.31 & LAC & 322.6 & $231 \pm 30$ & $0.58 \pm 0.04$ \\
\hline 920326 & $16: 30: 00.0$ & 37.27 & -116.36 & LAC & 319.8 & $235 \pm 31$ & $0.59 \pm 0.04$ \\
\hline 831030 & $01: 24: 51.1$ & 44.08 & -113.97 & LON & 679.0 & $370 \pm 30$ & $0.30 \pm 0.02$ \\
\hline 830317 & $07: 25: 56.6$ & 47.53 & -112.70 & LON & 696.0 & $444 \pm 70$ & $0.60 \pm 0.09$ \\
\hline 831212 & $04: 55: 36.3$ & 44.43 & -114.10 & LON & 654.6 & $456 \pm 15$ & $0.50 \pm 0.10$ \\
\hline 831030 & 01:59:01.4 & 44.22 & -114.19 & LON & 658.1 & $370 \pm 30$ & $0.76 \pm 0.04$ \\
\hline 831028 & $19: 51: 24.3$ & 44.07 & -113.91 & LON & 686.4 & $370 \pm 30$ & $0.67 \pm 0.04$ \\
\hline 840822 & $09: 46: 30.2$ & 44.47 & -114.01 & LON & 659.1 & $377 \pm 55$ & $0.51 \pm 0.04$ \\
\hline 840216 & 11:14:57.5 & 39.93 & -117.76 & LON & 825.9 & $383 \pm 12$ & $0.41 \pm 0.10$ \\
\hline 840324 & $00: 07: 47.8$ & 44.74 & -114.43 & LON & 616.3 & $384 \pm 71$ & $0.47 \pm 0.00$ \\
\hline 840908 & $13: 56: 37.6$ & 44.42 & -114.15 & LON & 651.5 & $265 \pm 67$ & $0.36 \pm 0.09$ \\
\hline 840908 & $06: 16: 40.2$ & 44.42 & -114.15 & LON & 650.5 & $382 \pm 47$ & $0.65 \pm 0.04$ \\
\hline 850821 & $18: 05: 38.2$ & 43.17 & -110.78 & LON & 956.3 & $450 \pm 10$ & $0.60 \pm 0.10$ \\
\hline 850206 & $19: 34: 19.5$ & 44.55 & -114.18 & LON & 641.5 & $314 \pm 87$ & $0.60 \pm 0.07$ \\
\hline 850401 & 09:13:14.2 & 47.28 & -113.23 & LON & 655.2 & $390 \pm 42$ & $0.70 \pm 0.04$ \\
\hline 850317 & $06: 56: 17.0$ & 44.55 & -114.18 & LON & 643.1 & $372 \pm 71$ & $0.52 \pm 0.06$ \\
\hline 821014 & $04: 10: 24.3$ & 42.59 & -111.43 & JAS & 922.9 & $431 \pm 124$ & $0.80 \pm 0.10$ \\
\hline 821110 & $11: 21: 25.6$ & 34.05 & -116.67 & JAS & 550.0 & $521 \pm 16$ & $0.31 \pm 0.10$ \\
\hline 831008 & $11: 57: 54.2$ & 40.75 & -111.99 & JAS & 791.7 & $444 \pm 63$ & $0.36 \pm 0.10$ \\
\hline 830713 & $21: 16: 48.2$ & 33.20 & -115.53 & JAS & 689.2 & $281 \pm 86$ & $0.60 \pm 0.07$ \\
\hline 831030 & $01: 59: 01.6$ & 44.08 & -113.97 & RSSD & 812.9 & $346 \pm 71$ & $0.75 \pm 0.08$ \\
\hline 830317 & $07: 25: 56.7$ & 47.53 & -112.70 & RSSD & 696.6 & $480 \pm 84$ & $0.80 \pm 0.07$ \\
\hline 831212 & $04: 55: 36.4$ & 44.43 & -114.10 & RSSD & 804.1 & $546 \pm 66$ & $0.70 \pm 0.03$ \\
\hline 831028 & $19: 51: 24.4$ & 44.07 & -113.91 & RSSD & 790.7 & $297 \pm 54$ & $1.08 \pm 0.09$ \\
\hline 840822 & $09: 46: 30.1$ & 44.47 & -114.01 & RSSD & 796.9 & $667 \pm 46$ & $0.50 \pm 0.04$ \\
\hline 841103 & $09: 30: 80.5$ & 42.49 & -108.85 & RSSD & 430.6 & $485 \pm 30$ & $0.52 \pm 0.03$ \\
\hline 850401 & $09: 13: 14.2$ & 47.28 & -113.23 & RSSD & 797.3 & $677 \pm 45$ & $0.50 \pm 0.03$ \\
\hline 850317 & $06: 57: 45.5$ & 44.55 & -114.18 & RSSD & 810.3 & $403 \pm 95$ & $0.78 \pm 0.07$ \\
\hline 811001 & $19: 00: 00.0$ & 37.08 & -116.01 & ALQ & 892.7 & $524 \pm 15$ & $0.40 \pm 0.10$ \\
\hline 810425 & 07:03:13.5 & 33.12 & -115.65 & ALQ & 872.4 & $494 \pm 14$ & $0.40 \pm 0.10$ \\
\hline 810606 & $18: 00: 00.0$ & 37.30 & -116.33 & ALQ & 925.8 & $422 \pm 66$ & $0.70 \pm 0.05$ \\
\hline 820415 & 21:52:08.7 & 38.04 & -118.50 & ALQ & 1064.0 & $604 \pm 14$ & $0.80 \pm 0.10$ \\
\hline 820212 & 41:55:00.1 & 37.22 & -116.46 & ALQ & 935.6 & $465 \pm 10$ & $0.80 \pm 0.07$ \\
\hline 811112 & 15:00:00.2 & 37.11 & -116.05 & ANMO & 869.8 & $386 \pm 62$ & $0.20 \pm 0.09$ \\
\hline 811001 & $19: 00: 00.0$ & 37.08 & -116.01 & ANMO & 892.7 & $360 \pm 93$ & $0.10 \pm 0.04$ \\
\hline 810606 & $18: 00: 00.0$ & 37.30 & -116.33 & ANMO & 925.7 & $397 \pm 67$ & $0.50 \pm 0.08$ \\
\hline
\end{tabular}




\section{Lg Coda Q}

Table 4. (continued)

\begin{tabular}{|c|c|c|c|c|c|c|c|}
\hline Date & $\begin{array}{l}\text { Origin } \\
\text { (h:m:s) }\end{array}$ & $\begin{array}{c}\text { Lat } \\
\left(\mathrm{O}^{\mathrm{N}}\right)\end{array}$ & $\begin{array}{l}\text { Lon } \\
(\mathrm{OE})\end{array}$ & $\begin{array}{l}\text { Recording } \\
\text { station }\end{array}$ & $\begin{array}{c}\text { Distance } \\
\text { (km) }\end{array}$ & $\mathbf{Q}_{0}$ & $\eta$ \\
\hline 810425 & $07: 03: 13.7$ & 33.12 & -115.65 & ANMO & 872.5 & $414 \pm 13$ & $0.60 \pm 0.10$ \\
\hline 820524 & $12: 13: 26.9$ & 38.71 & -112.04 & ANMO & 646.7 & $324 \pm 78$ & $0.40 \pm 0.07$ \\
\hline 821014 & $04: 10: 00.3$ & 42.59 & -111.43 & ANMO & 952.0 & $257 \pm 97$ & $0.50 \pm 0.10$ \\
\hline 820212 & $14: 55: 00.2$ & 37.22 & -116.46 & ANMO & 935.5 & $564 \pm 10$ & $0.70 \pm 0.10$ \\
\hline 820425 & 18:04:59.9 & 37.26 & -116.44 & ANMO & 935.2 & $399 \pm 65$ & $0.40 \pm 0.10$ \\
\hline 820706 & $02: 10: 43.4$ & 34.95 & -106.46 & ANMO & 829.4 & $218 \pm 41$ & $0.30 \pm 0.09$ \\
\hline 830703 & $18: 40: 08.3$ & 37.54 & -118.86 & ANMO & 1110.5 & $300 \pm 92$ & $0.90 \pm 0.09$ \\
\hline 831209 & 08:58:41.4 & 38.58 & -112.58 & ANMO & 549.8 & $275 \pm 66$ & $0.41 \pm 0.08$ \\
\hline 910817 & $19: 29: 39.9$ & 40.26 & -124.30 & ANMO & 1712.9 & $466 \pm 12$ & $1.00 \pm 0.10$ \\
\hline 920629 & $10: 14: 22.2$ & 36.71 & -116.29 & ANMO & 937.7 & $386 \pm 74$ & $0.61 \pm 0.09$ \\
\hline 921204 & 02:08:57.4 & 34.37 & -116.90 & ANMO & 976.2 & $359 \pm 64$ & $0.50 \pm 0.06$ \\
\hline 940204 & $02: 42: 11.9$ & 42.71 & -111.03 & ANMO & 994.1 & $504 \pm 18$ & $0.90 \pm 0.10$ \\
\hline 910817 & 19:29:39.9 & 40.26 & -124.30 & $\mathrm{COR}$ & 487.6 & $231 \pm 52$ & $0.40 \pm 0.10$ \\
\hline 920308 & $03: 43: 04.6$ & 40.24 & -123.99 & COR & 486.6 & $208 \pm 52$ & $0.21 \pm 0.10$ \\
\hline 930325 & 13:34:00.0 & 45.04 & -122.61 & COR & 073.3 & $186 \pm 19$ & $0.30 \pm 0.03$ \\
\hline 940119 & 22:27:31.2 & 42.30 & -121.96 & COR & 276.3 & $303 \pm 88$ & $0.60 \pm 0.10$ \\
\hline 920624 & $07: 31: 20.8$ & 38.89 & -111.46 & TUC & 763.3 & $359 \pm 97$ & $0.72 \pm 0.11$ \\
\hline 921204 & 02:08:57.4 & 34.37 & -116.90 & TUC & 613.2 & $325 \pm 57$ & $0.39 \pm 0.06$ \\
\hline 930429 & 08:21:00.9 & 35.58 & -112.12 & TUC & 402.3 & $330 \pm 56$ & $0.52 \pm 0.06$ \\
\hline 930528 & $04: 47: 40.5$ & 35.09 & -119.15 & TUC & 834.4 & $293 \pm 69$ & $0.54 \pm 0.09$ \\
\hline 930517 & $23: 20: 49.1$ & 37.10 & -117.80 & TUC & 833.5 & $385 \pm 80$ & $0.70 \pm 0.09$ \\
\hline 930528 & 04:47:38.9 & 35.09 & -119.15 & TUC & 833.2 & $207 \pm 73$ & $0.28 \pm 0.18$ \\
\hline 930520 & $20: 14: 14.0$ & 36.02 & -117.64 & TUC & 753.7 & $253 \pm 40$ & $0.30 \pm 0.08$ \\
\hline 930518 & 01:03:06.4 & 37.10 & -117.75 & TUC & 830.0 & $302 \pm 80$ & $0.46 \pm 0.10$ \\
\hline 940211 & $14: 59: 49.5$ & 42.76 & -110.99 & TUC & 1160.5 & $363 \pm 16$ & $0.86 \pm 0.15$ \\
\hline 940117 & $12: 30: 55.3$ & 34.21 & -118.54 & TUC & 752.3 & $304 \pm 47$ & $0.54 \pm 0.05$ \\
\hline 940204 & $02: 42: 11.9$ & 42.71 & -111.03 & TUC & 1154.5 & $330 \pm 88$ & $0.51 \pm 0.10$ \\
\hline 910817 & $19: 29: 39.9$ & 40.26 & -124.30 & GSC & 890.0 & $304 \pm 57$ & $0.51 \pm 0.09$ \\
\hline 930528 & $04: 47: 40.5$ & 35,09 & -119.15 & GSC & 243.6 & $234 \pm 23$ & $0.30 \pm 0.04$ \\
\hline 930517 & $23: 20: 49.0$ & 37.10 & -117.80 & GSC & 243.9 & $379 \pm 10$ & $0.65 \pm 0.10$ \\
\hline 930210 & $21: 48: 34.9$ & 40.43 & -119.60 & GSC & 644.5 & $238 \pm 42$ & $0.32 \pm 0.08$ \\
\hline 930116 & $06: 29: 34.8$ & 36.90 & -121.60 & GSC & 461.9 & $235 \pm 56$ & $0.40 \pm 0.09$ \\
\hline 940117 & $12: 30: 55.3$ & 34.21 & -118.54 & GSC & 216.0 & $320 \pm 62$ & $0.69 \pm 0.09$ \\
\hline 940204 & $14: 59: 50.5$ & 42.71 & -111.03 & GSC & 966.6 & $395 \pm 17$ & $0.70 \pm 0.20$ \\
\hline 921204 & 02:08:57.4 & 34.37 & -116.90 & ISA & 202.4 & $238 \pm 66$ & $0.49 \pm 0.01$ \\
\hline 920629 & $10: 14: 22.2$ & 36.71 & -116.29 & ISA & 227.4 & $279 \pm 49$ & $0.41 \pm 0.09$ \\
\hline 930116 & $06: 29: 35.8$ & 36.90 & -121.60 & ISA & 307.1 & $225 \pm 38$ & $0.30 \pm 0.07$ \\
\hline 930210 & $21: 48: 35.1$ & 40.43 & -119.60 & ISA & 538.8 & $207 \pm 41$ & $0.30 \pm 0.07$ \\
\hline 921204 & 02:09:03.1 & 34.37 & -116.90 & MLA & 402.3 & $217 \pm 56$ & $0.37 \pm 0.10$ \\
\hline 930528 & $04: 47: 40.6$ & 35.09 & -119.15 & MLA & 283.1 & $207 \pm 32$ & $0.30 \pm 0.07$ \\
\hline 910817 & $19: 29: 39.9$ & 40.26 & -124.30 & PAS & 869.2 & $299 \pm 66$ & $0.54 \pm 0.09$ \\
\hline 920629 & $10: 14: 22.1$ & 36.71 & -116.29 & PAS & 733.3 & $290 \pm 14$ & $0.63 \pm 0.33$ \\
\hline 930517 & $23: 20: 49.2$ & 37.10 & -117.80 & PAS & 329.2 & $279 \pm 48$ & $0.60 \pm 0.06$ \\
\hline 930517 & $23: 20: 49.1$ & 37.10 & -117.80 & $\mathrm{CMB}$ & 251.3 & $286 \pm 74$ & $0.31 \pm 0.08$ \\
\hline 930528 & $04: 47: 40.5$ & 35.09 & -119.15 & $\mathrm{CMB}$ & 344.6 & $218 \pm 35$ & $0.23 \pm 0.05$ \\
\hline 930116 & $06: 29: 34.9$ & 36.90 & -121.60 & CMB & 173.3 & $218 \pm 39$ & $0.25 \pm 0.05$ \\
\hline 910817 & $19: 29: 39.9$ & 40.26 & -124.30 & SBC & 762.9 & $291 \pm 74$ & $0.45 \pm 0.12$ \\
\hline 921204 & 02:08:57.5 & 34.37 & -116.90 & SBC & 258.0 & $245 \pm 48$ & $0.30 \pm 0.08$ \\
\hline 920629 & $10: 14: 22.1$ & 36.71 & -116.29 & MHC & 481.0 & $287 \pm 46$ & $0.31 \pm 0.08$ \\
\hline 930528 & $04: 47: 40.6$ & 35.09 & -119.15 & PFO & 297.3 & $237 \pm 45$ & $0.20 \pm 0.07$ \\
\hline 930116 & $06: 29: 34.9$ & 36.90 & -121.60 & ARC & 500.3 & $265 \pm 70$ & $0.50 \pm 0.17$ \\
\hline 920629 & $10: 14: 22.9$ & 36.71 & -116.29 & STAN & 528.7 & $348 \pm 48$ & $0.49 \pm 0.06$ \\
\hline 920629 & $10: 14: 22.2$ & 36.71 & -116.29 & SAO & 459.8 & $335 \pm 68$ & $0.51 \pm 0.08$ \\
\hline 910817 & 19:29:40.1 & 40.26 & -124.30 & WCK & 576.4 & $404 \pm 45$ & $0.71 \pm 0.05$ \\
\hline 920629 & $10: 14: 22.2$ & 36.71 & -116.29 & BKS & 543.1 & $304 \pm 49$ & $0.66 \pm 0.07$ \\
\hline
\end{tabular}

The origin times and locations are from the U.S. Geological Survey's Preliminary Determination of Epicenters; The $Q_{0}$ and $\eta$ values with standard error for each path are obtained in this study. 


\section{Lg Coda Q}

Mapping Lg Coda $Q$ Variations - Method

Although seismic tomography has been very successful in mapping velocities in the Earth, it has not been used extensively to map variations of attenuative properties. The first such study for regional phases was done for the African continent where a set of Lg coda records that covered much of the continent was assembled and the SSR method was applied to them (Xie and Mitchell, 1990a). As discussed earlier, the resulting tomographic image revealed striking regional variations of $\mathrm{Q}_{\mathrm{Lg}}^{\mathrm{c}}$ that coincide with some of the major tectonic features of Africa.

In the present study we apply the same method to United States. It is a back-projection algorithm that produces a tomographic image of $Q_{\mathrm{Lg}}^{\mathrm{c}}$ over any broad region using a number, $\left(\mathrm{N}_{\mathrm{d}}\right)$ of individual determinations of $\mathrm{Q}_{\mathrm{Lg}}^{\mathrm{c}}$ from $\mathrm{Lg}$ coda recordings within that region. Since $\mathrm{Lg}$ coda consists of scattered waves the energy arriving at a recording station does not follow a straight path between from the seismic event, but is contained within a volume of the crust that includes the source and recording station.

For single scattering the surface projection of the scattered energy takes the form of an ellipse with the source at one focus and the recording station at the other. The ellipse covers a larger and larger area as the lag time of the coda increases. The elliptical areas for the event-station pairs used in this study are shown in Figure 8 at the maximum lapse time used for the SSR analysis described earlier. If coda waves are scattered through a volume as approximated by the elliptical surface projections in Figure 8, and if many events and recording stations are available, then much overlap occurs among some of the ellipses. This overlap provides data redundancy that is ideal for applying modern inversion techniques to map regional variations of attenuation.

To apply the tomographic method we divided the United States into a number, $\mathrm{N}_{\mathrm{c}}$, of cells that are small enough to allow us to resolve tectonic features of interest. $\mathrm{Q}_{\mathrm{m}}, \mathrm{Lg}$ coda $\mathrm{Q}$ within the mth cell, is assumed to be constant throughout the cell. We take the cell dimensions to be $2^{\circ} \times 2^{\circ}$. $Q_{n}$, the $\mathrm{Lg}$ coda $\mathrm{Q}$ value calculated for the nth time series, gives the areal average of $\mathrm{Lg}$ coda $\mathrm{Q}$ over the elliptical area sampled by the coda waves received at the maximum lapse time of the $\mathrm{Lg}$ coda waves of interest. If we denote the area that the nth ellipse overlaps the mth cell by $s_{m n}$, then

where

$$
\frac{1}{Q_{n}}=\frac{1}{S_{n}} \sum_{m=1}^{N_{c}} \frac{s_{m n}}{Q_{m}}+\varepsilon_{n}, \quad \mathrm{n}=1,2, \ldots, \mathrm{N}_{\mathrm{d}}
$$

$$
S_{n}=\sum_{j=1}^{N_{c}} s_{j n}
$$

and $\varepsilon_{\mathrm{n}}$ is the residual due to the errors in the measurement and modeling of Lg coda. We solve (5) by a back-projection, or ART technique (Gordon, 1974), that has been used successfully in seismic velocity tomography. The numerical procedure used to obtain that solution is described by Xie and Mitchell (1990a) and will not be repeated here.

A disadvantage of the back-projection technique is that it does not provide formal estimates of resolution or standard error. Humphreys and Clayton (1988) have, however, suggested using a "point spreading function" as an approximation for the resolution kernel. The point spreading function (hereafter abbreviated $p s f$ ) is obtained by constructing a 
4. Lig Coda Q

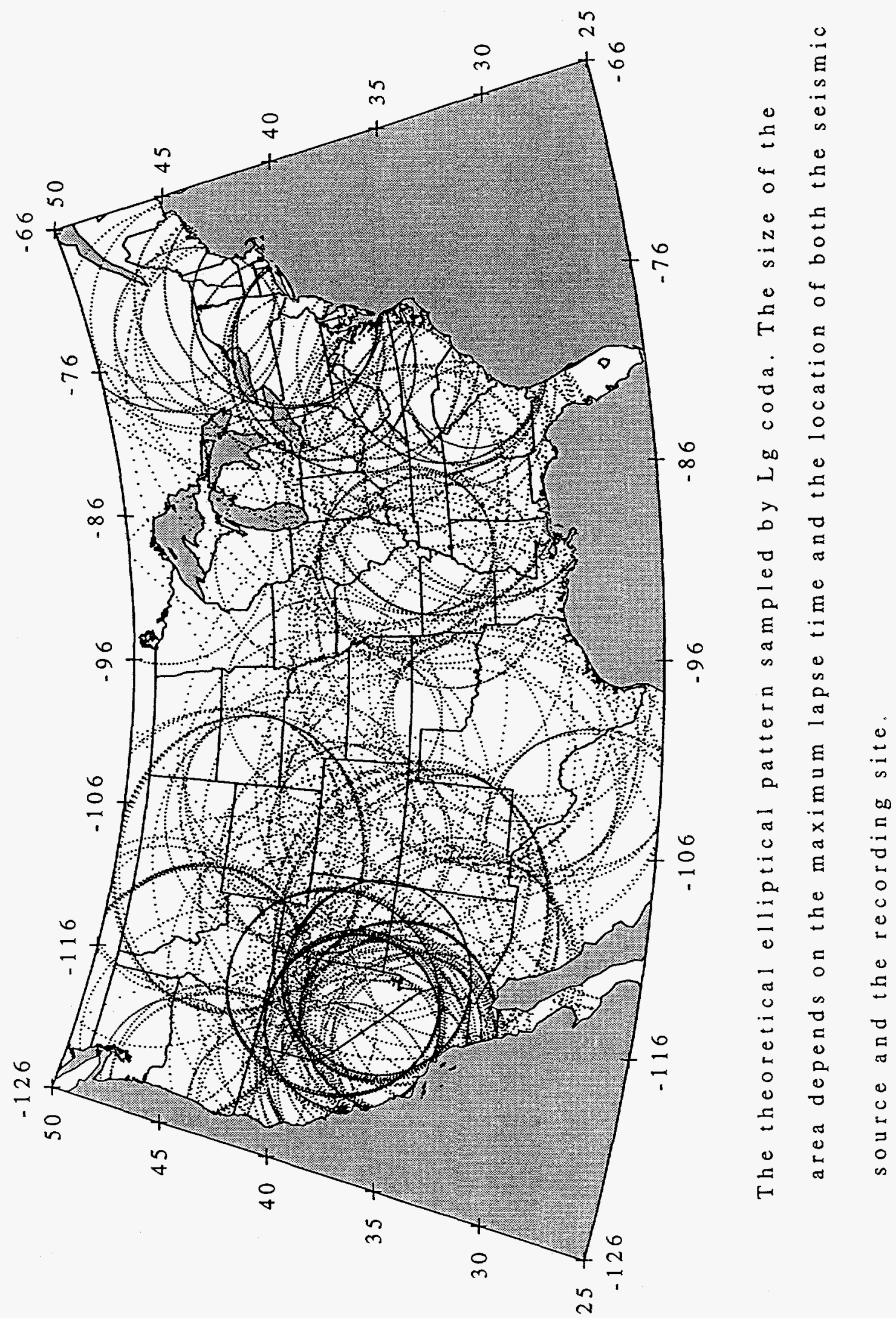

$\infty$
0
4
3
0
0
01
01
01 


\section{Lg Coda Q}

model in which $\mathrm{Q}^{-1}$ has the value of unity in a single cell at the geographical point of interest and is zero everywhere else. We then compute synthetic data using this model and perform an inversion using the same event-station pair locations that are available to us. The resulting image gives the psf at the point of interest, a quantity whose area and falloff with distance from the central cell gives a measure of resolution.

The effect that random noise on $\mathrm{Lg}$ coda has on our tomographic images can be empirically tested using the sample standard error in $Q_{n}$ caused by randomness of the SSR's. If the standard error for each determination of $Q_{n}$ is denoted by $\delta Q_{n}, n=1,2, \ldots$ $\mathrm{N}_{\mathrm{d}}$, we can construct a noise series for each $\mathrm{Lg}$ coda time series that has an absolute value equal to $\delta Q_{n}$ and a sign that is chosen randomly. The nth term of the noise series is added to $Q_{n}$ and the sums of the two series are then inverted to obtain a new $Q_{m}$ image. The difference between this image and the original one gives us an error estimate for the $\mathrm{Q}_{\mathrm{m}}$ values. Since the sign of $\delta Q_{n}$ is chosen by a random binary generator, the process should be repeated several times to obtain an average error estimate.

\section{Mapping Lg Coda Q Variations - Results}

We used the back projection method described above to image lateral variations of $\mathrm{Lg}$ coda $\mathrm{Q}$ across most of the United States. The map depicting $\mathrm{Lg}$ coda scattering ellipses (Figure 8) indicates the extent of our data coverage. We inverted the $Q_{\mathrm{Lg}}^{c}$ data using equation 9 and a starting model in which $\mathrm{Q}_{\mathrm{m}}^{\circ}=600, \mathrm{~m}=1,2, \ldots, \mathrm{N}_{\mathrm{c}}$ for the entire region of study. The equation was inverted using our measured $Q_{0}$ values and the areas of each ellipse at a time late in the coda. Residuals were calculated for each iteration and the stopping criterion was either that the number of iterations reached 20 or the relative change in the sum of squares of residuals became less than $10^{-5}$. Figure 9 displays a tomographic image of $Q_{0}$ for the United States using symbols to denote $Q_{0}$ values and Figure 10 is the same map using color coding. $Q_{0}$ ranges between about 250 and about 750 , in a pattern that exhibits a predominant east-to-west trend of decreasing $Q$.

The process for determining the frequency dependence of $\mathrm{Lg}$ coda $\mathrm{Q}$ begins by using the $Q_{0}$ and $\eta$ values obtained for each trace to estimate $L g$ coda $Q$ at another frequency; that being $3 \mathrm{~Hz}$ in this study. These new values were used as $Q_{n}$ in equation 5 and yielded a map of $\mathrm{Lg}$ coda $\mathrm{Q}$ at $3 \mathrm{~Hz}$. Using the maps of $\mathrm{Lg}$ coda $Q$ at $1 \mathrm{~Hz}$ and $3 \mathrm{~Hz}$ we calculated the frequency dependence of $\operatorname{Lg}$ coda $Q$ using the relationship

$$
\eta=\frac{1}{\ln 3} \ln \left[\frac{Q(f)_{3 H z}}{Q_{o}}\right]
$$

Figure 11 shows the distribution of $\eta$ across the United States resulting from this process.

\section{Resolution and Error}

Figure 12 presents psf plots for three selected regions of the United States. As discussed earlier the areas covered by these plots and the rapidity of their falloff with distance from the center cell can be used to estimate our ability to resolve features of the mapped $Q_{0}$ and $\eta$ distributions. The resolution in the western and eastern regions are similar to one another and somewhat better than that for the central region.

The method described in the previous section permits estimates of the effect of random errors in $\mathrm{Lg}$ coda $\mathrm{Q}$ measurements on our images of $\mathrm{Q}_{0}$ and $\eta$. Five tests were run to estimate the error in the images of the two quantities. In each of the tests we constructed 
4. Lg Coda Q

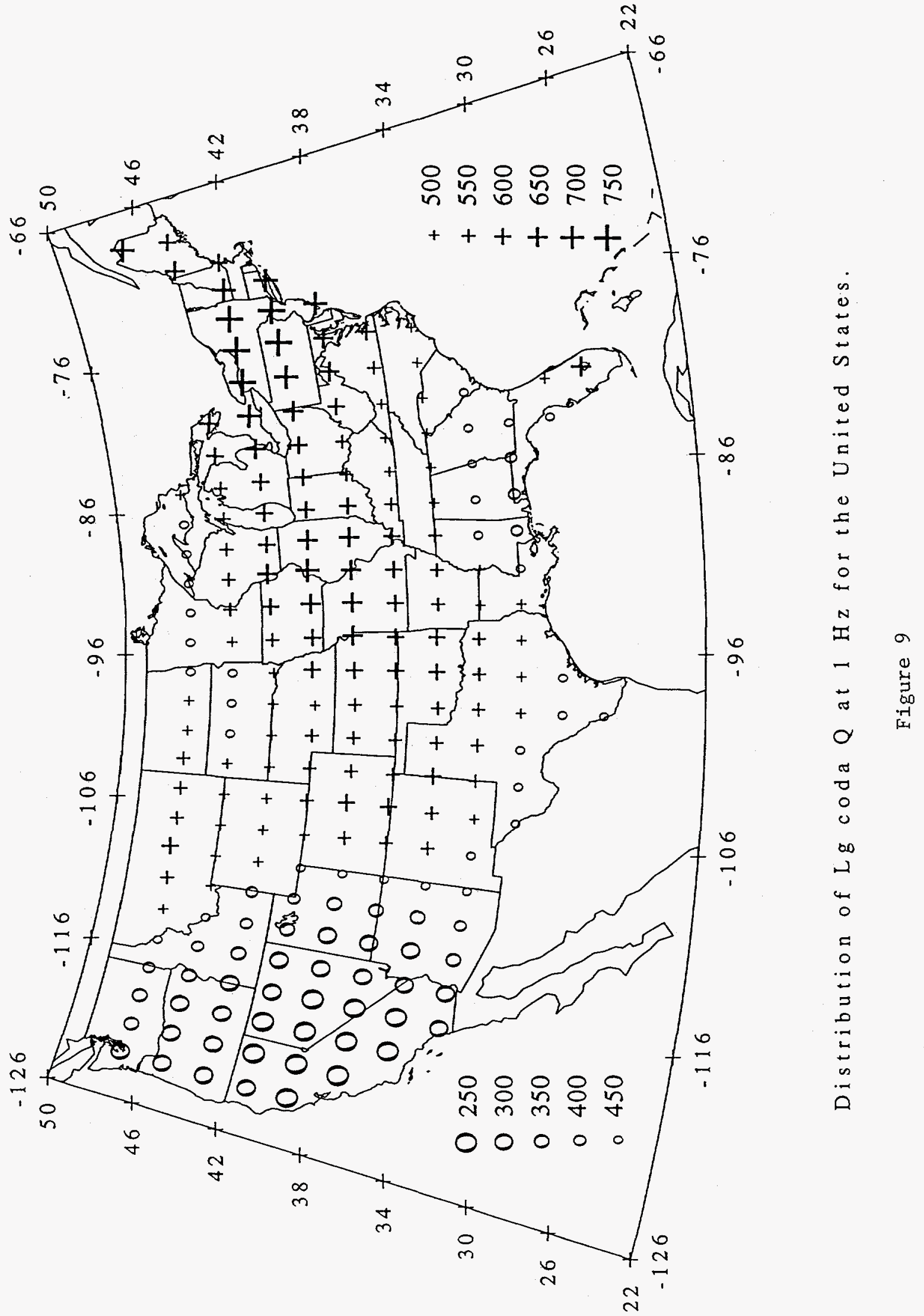




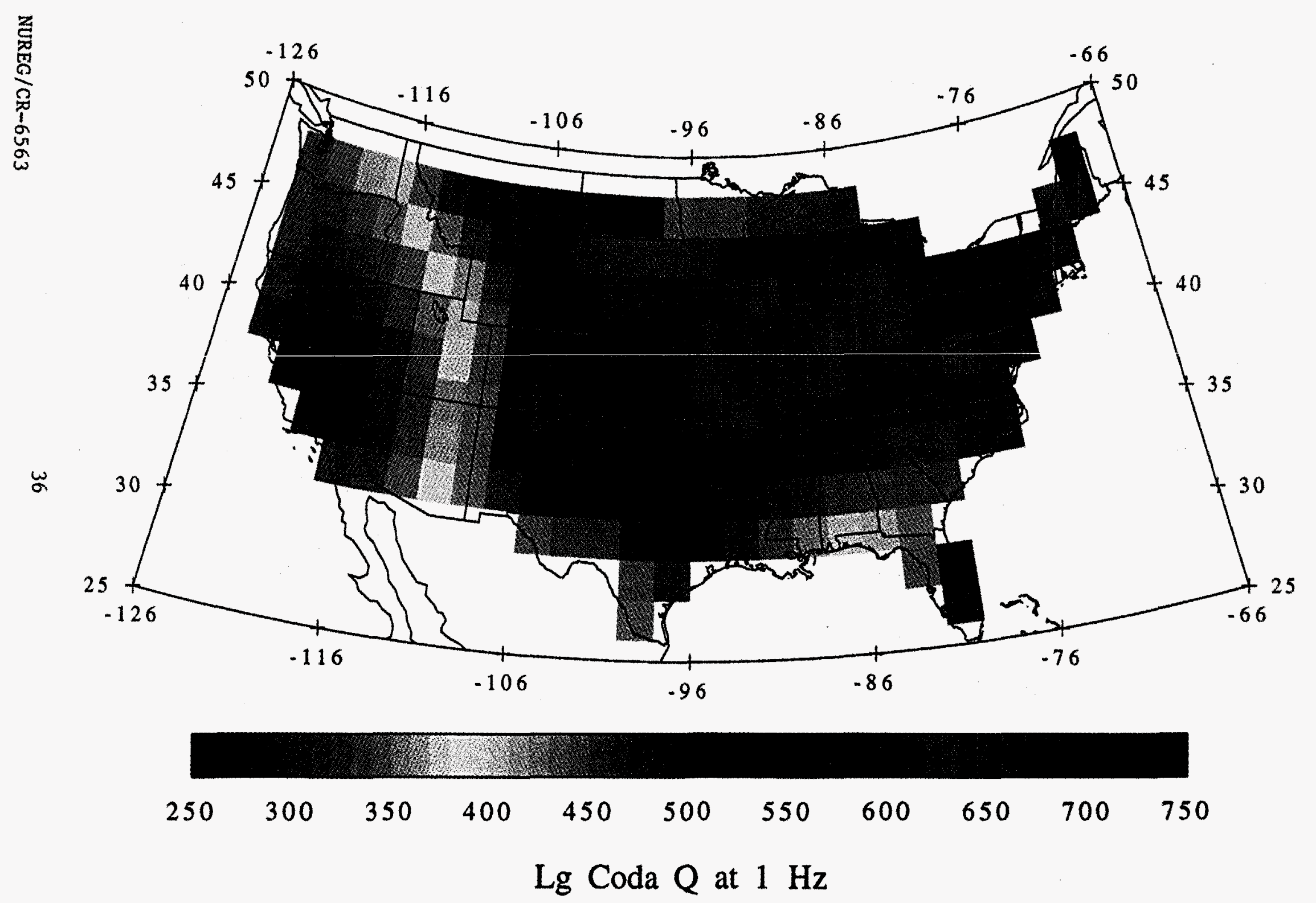






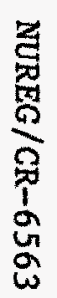

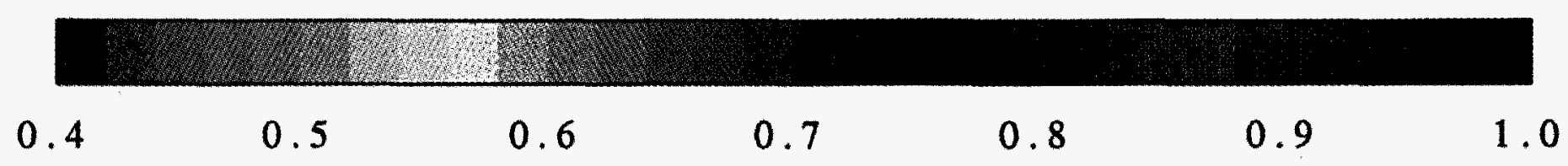

Frequency Dependence of $\mathrm{Lg}$ Coda $\mathrm{Q}$ 
4. Lg Coda Q
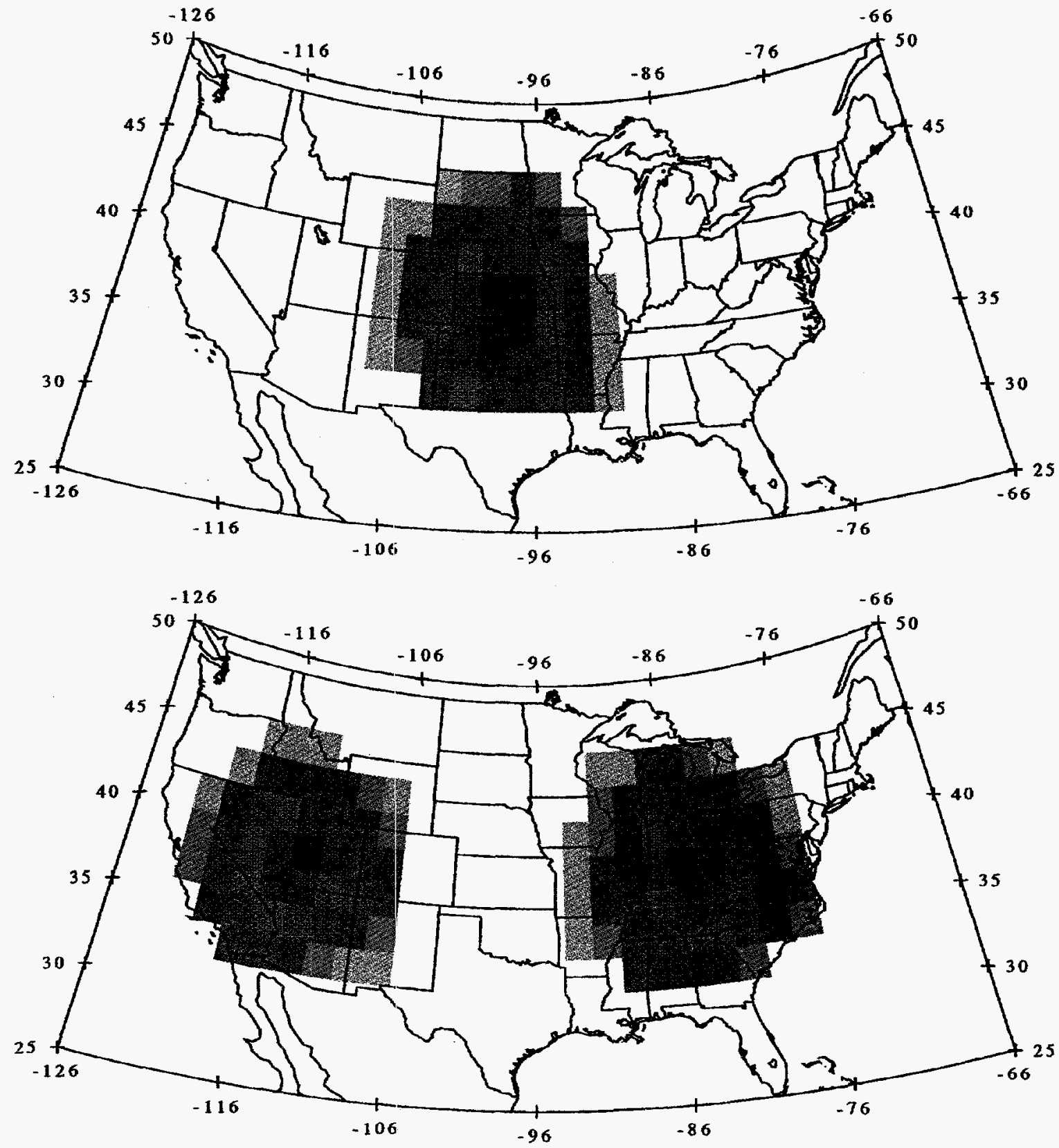
0.1
0.20 .3
0.4
0.5
0.6
0.7
0.8
0.91 .0

Relative Value of psf

Figure 12 
4. Lg Coda Q

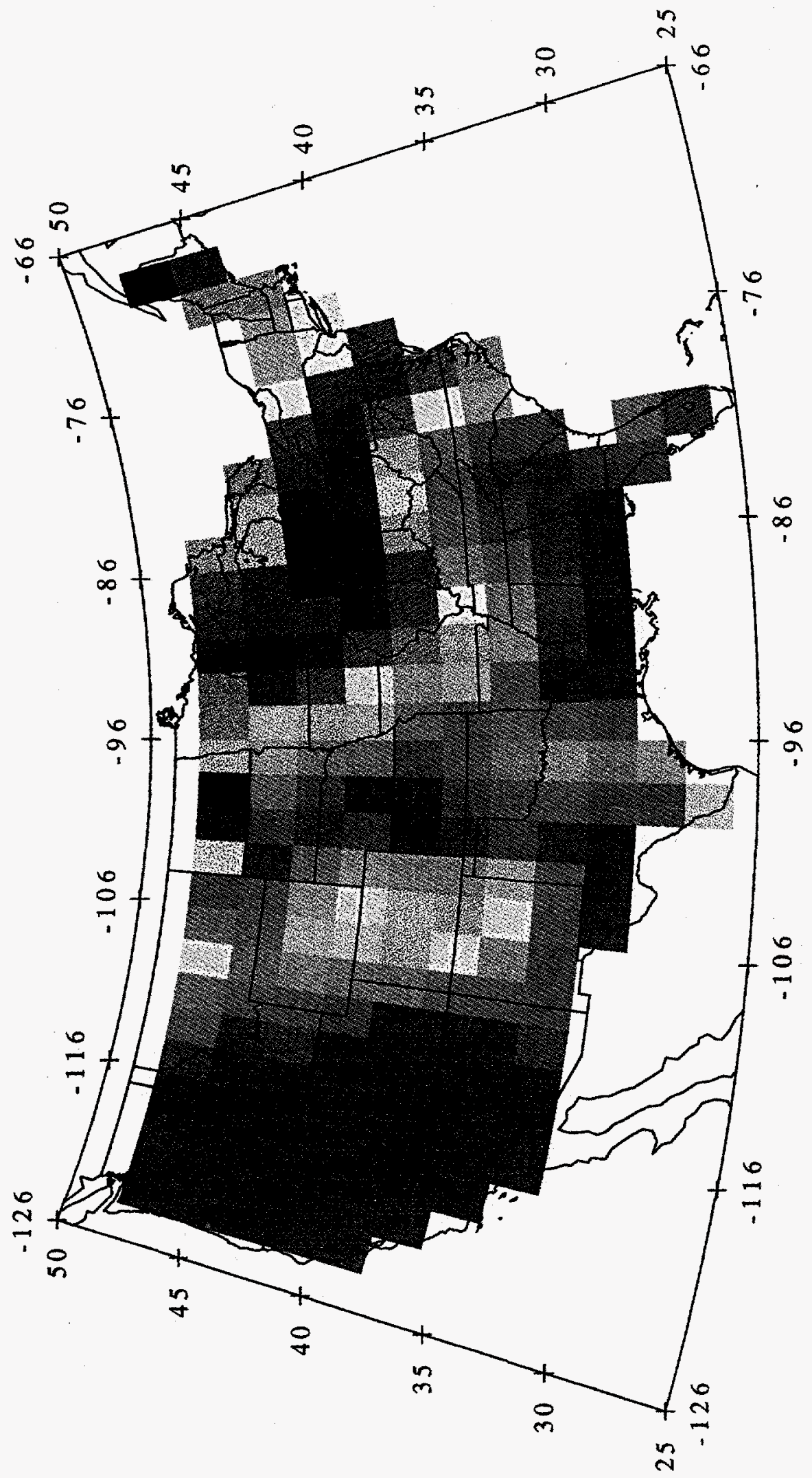

$\infty$

은

용

N

5

o 


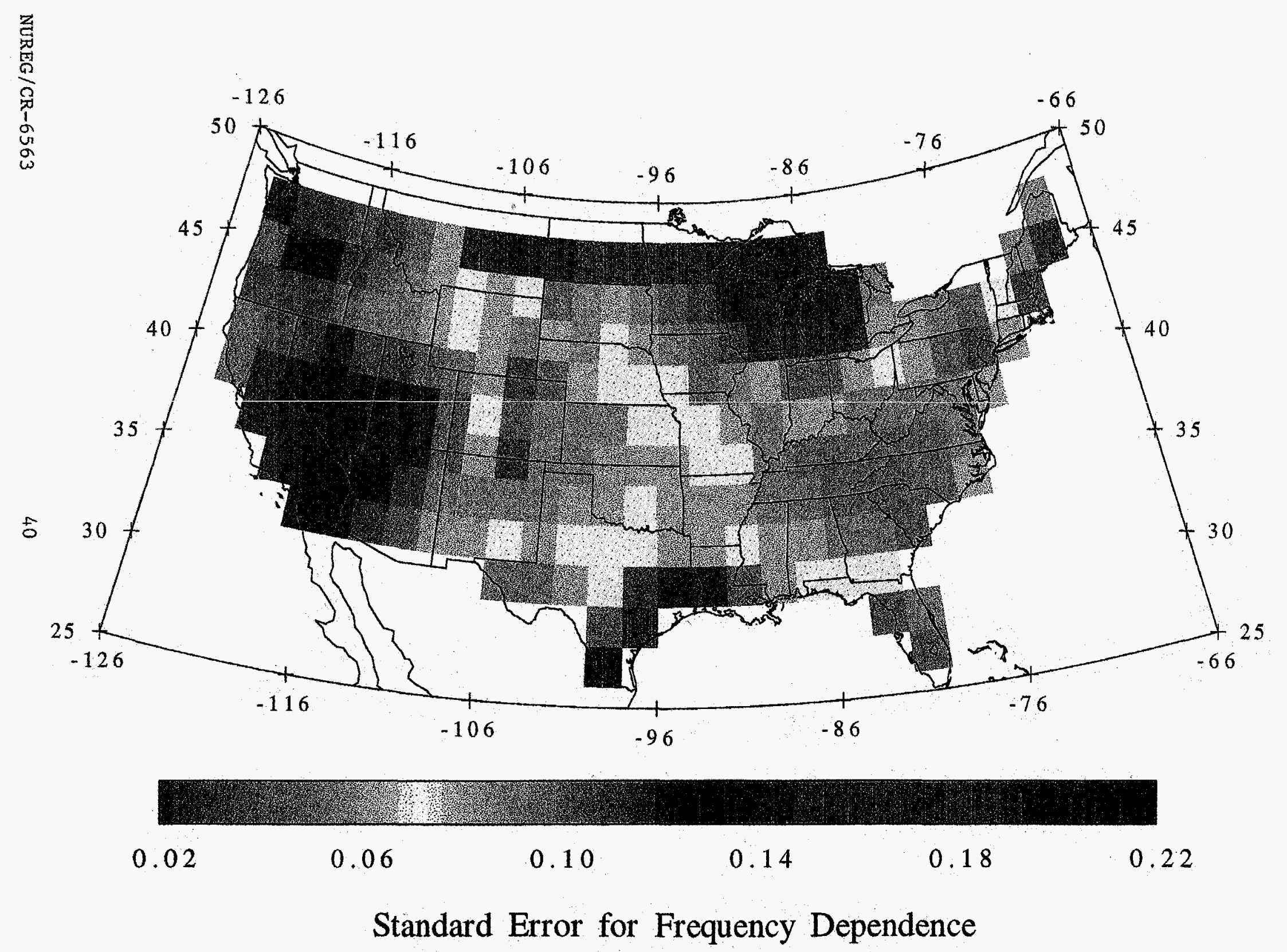

5
5
0
0
0
0
0

Figure 14 
two noise series, in both of which the absolute values of the nth terms equal the standard errors found for $Q_{0}$ and $\eta$ from the nth coda seismogram. The signs of the nth terms were generated by a random binary generator. The nth terms of the two noise series were then added to the nth measurements of $Q_{0}$ and $\eta$ measurements to construct new synthetic maps of $Q_{0}$ and $\eta$. The differences between these new maps and the original ones were calculated and stored after each test. The average values of the differences for the five tests give empirical estimates of absolute error in $Q_{o}$ and $\eta$ as shown in Figures 13 and 14.

\section{Conclusions}

Source parameters for events selected for this study indicate that both comer frequency and magnitude vary systematically with moment for earthquakes in the central and eastern United States. The moments of events used in this study vary between about 0.15 and 400 $X 10^{15} \mathrm{~N}$-m. Over that range, corner frequency varies between about $4 \mathrm{~Hz}$ and $0.2 \mathrm{~Hz}$ and body-wave magnitude varies between about 3.5 and 5.8 .

Lg Q and Lg coda Q both vary systematically from east to west with the lowest values occurring in the westernmost United States. The excellent coverage for $\mathrm{Lg}$ coda $Q$ has permitted us to obtain a tomographic image of those values. Lg coda $Q$ values are highest in a region of the northeastern United States that includes portions of New York and Pennsylvania (700-750) and lowest throughout much of California. Another region of relatively high $Q$ lies in the central United States in portions of Missouri, Illinois, and Iowa $(650-700)$. The entire western portion of the United States west of the Rocky Mountains is characterized by much lower Lg coda Q values (250-400) than the rest of the country 450 750). These results indicate that for an earthquake of a given magnitude $\mathrm{Lg}$ and its coda will propagate much more efficiently (and cause damage or be felt over a larger area) in the eastern United States than it will in the western United States.

\section{References}

Aki, K., Analysis of the seismic coda of local earthquakes as scattered waves, $J$ Geophys. Res., 74, 615-631, 1969.

Aki, K., and B. Chouet, Origin of coda waves: source, attenuation, and scattering effects, J. Geophys. Res., 80, 3322-3342, 1975.

Baker, R.G., Determining magnitude from Lg, Bull. Seism. Soc. Am., 60, 1907-1919, 1970.

Campillo, M., and J.L. Plantee, Frequency dependence and spatial distribution of seismic attenuation in France: Experimental results and possible interpretation, Phys. Earth Planet. Int., 67, 48-65, 1991.

Cong, L., J. Xie, and B.J. Mitchell, Excitation and propagation of Lg from earthquakes in central Asia with implications for explosion/earthquake discrimination, J. Geophys. Res., 101, 27779-27789, 1996.

Der, Z.A., M.A. Marshall, A. O'Donnell, and T.W. McElfresh, Spatial coherence structure and attenuation of the Lg phase, site effects, and the interpretation of the $\mathrm{Lg}$ coda, Bull. Seism. Soc. Am., 74, 1125-1147, 1984. 


\section{References}

Gordon, R., A tutorial on ART, IEEE Trans. Nucl. Sci., NS-21, 78-93, 1974.

Haar, L.C., C.S. Mueller, J.B. Fletcher, and D.M. Boore, Comments on "some recent Lg phase displacement spectral densities and their implications with respect to prediction of ground motions in eastern North America" by R. Street, Bull. Seism. Soc. Am., 76, 291-295, 1986.

Humphreys, E., and R.W. Clayton, Adaptation of back projection tomography to seismic travel time problems, J. Geophys. Res., 93, 1073-1086, 1988.

Kennett, B.L.N., Guided wave propagation in laterally varying media - I. Theoretical development, Geophys. J. Roy. Astr. Soc., 79, 235-255, 1984.

Knopoff, L., F. Schwab, and E. Kausel, Interpretation of Lg, Geophys. J. Roy. Astr. Soc., 33, 389-404, 1973.

Mitchell, B.J., Regional variation and frequency dependence of $\mathrm{Q}_{\beta}$ in the crust of the United States, Bull. Seism. Soc. Am., 71, 1531-1538, 1981.

Mitchell, B.J., Anelastic structure and evolution of the continental crust and upper mantle from seismic surface wave attenuation, Rev. Geophys., 33, 441-462, 1995.

Nuttli, O.W., Seismic wave attenuation and magnitude relations for eastern North America, J. Geophys. Res., 78, 876-885, 1973.

Nuttli, O.W., Yield estimates of Nevada test site explosions obtained from seismic Lg waves, J. Geophys. Res., 91, 2137-2152, 1986.

Panza, G.F., and G. Calcagnile, Lg, Li, and Rg from Rayleigh modes, Geophys. J. Roy. Astr. Soc., 40, 475-487, 1975.

Shi, J., W. Kim, and P.G. Richards, Variability of crustal attenuation in the northeastern United States, J. Geophys. Res., 101, 25231-25242, 1996.

Xie, J., Simultaneous inversion of source spectra and path Q using Lg with applications to three Semipalatinsk explosions, Bull. Seism. Soc. Am., 83, 1547-1562, 1993.

Xie, J., and O.W. Nuttli, Interpretation of high-frequency coda at large distances: Stochastic modeling and method of inversion, Geophys. J., 95, 579-595, 1988.

Xie, J., and B.J. Mitchell, A back-projection method for imaging large-scale lateral variations of Lg coda Q with application to continental Africa, Geophys. J. Int., 100, 161-181, 1990a.

Xie, J., and B.J. Mitchell, Attenuation of multiphase surface waves in the Basin and Range province, I, Lg and Lg coda, Geophys. J. Int., 102, 121-137, $1990 \mathrm{~b}$.

Xie, J., L. Cong, and B.J. Mitchell, Spectral characteristics of the excitation and propagation of $\mathrm{Lg}$ from underground nuclear explosions in central Asia, J. Geophys. Res., 101, 5813-5822, 1996. 